ARTICLE

DOI: 10.1038/s41467-018-04353-y OPEN

\title{
LRRC8/VRAC anion channels enhance $\beta$-cell glucose sensing and insulin secretion
}

\author{
Till Stuhlmann ${ }^{1,2}$, Rosa Planells-Cases ${ }^{1} \&$ Thomas J. Jentsch (1D ${ }^{1,3}$
}

Glucose homeostasis depends critically on insulin that is secreted by pancreatic $\beta$-cells. Serum glucose, which is directly sensed by $\beta$-cells, stimulates depolarization- and $\mathrm{Ca}^{2+}$ dependent exocytosis of insulin granules. Here we show that pancreatic islets prominently express LRRC8A and LRRC8D, subunits of volume-regulated VRAC anion channels. Hypotonicity- or glucose-induced $\beta$-cell swelling elicits canonical LRRC8A-dependent VRAC currents that depolarize $\beta$-cells to an extent that causes electrical excitation. Glucose-induced excitation and $\mathrm{Ca}^{2+}$ responses are delayed in onset, but not abolished, in $\beta$-cells lacking the essential VRAC subunit LRRC8A. Whereas Lrrc8a disruption does not affect tolbutamide- or high- $\mathrm{K}^{+}$-induced insulin secretion from pancreatic islets, it reduces first-phase glucoseinduced insulin secretion. Mice lacking VRAC in $\beta$-cells have normal resting serum glucose levels but impaired glucose tolerance. We propose that opening of LRRC8/VRAC channels increases glucose sensitivity and insulin secretion of $\beta$-cells synergistically with $\mathrm{K}_{\text {ATP }}$ closure. Neurotransmitter-permeable LRRC8D-containing VRACs might have additional roles in autocrine/paracrine signaling within islets.

\footnotetext{
${ }^{1}$ Leibniz-Forschungsinstitut für Molekulare Pharmakologie (FMP) and Max-Delbrück-Centrum für Molekulare Medizin (MDC), Robert-Rössle-Strasse 10, 13125 Berlin, Germany. ${ }^{2}$ Graduate Program of the Faculty for Biology, Chemistry and Pharmacy, Freie Universität Berlin, 14195 Berlin, Germany. ${ }^{3}$ Neurocure Cluster of Excellence, Charité Universitätsmedizin Berlin, 10117 Berlin, Germany. Correspondence and requests for materials should be addressed to T.J.J. (email: jentsch@fmp-berlin.de)
} 
nsulin, the only hormone that lowers blood glucose concentrations, is produced and secreted by pancreatic $\beta$-cells that constitute about $75 \%$ of the islets of Langerhans. Failure to secrete sufficient amounts of insulin results in diabetes mellitus, a common pathology with serious long-term complications that affect several tissues. A rise in serum glucose cell autonomously stimulates $\beta$-cell insulin secretion ${ }^{1}$. Glucose sensing by $\beta$-cells involves glucose transporter-mediated cellular uptake of glucose and its conversion to ATP and other metabolites. The rise in ATP inhibits $\mathrm{K}_{\mathrm{ATP}}$ channels (ATPsensitive potassium channels) expressed in the plasma membrane of $\beta$-cells. Since these channels largely control their resting potential, $\mathrm{K}_{\mathrm{ATP}}$ closure depolarizes $\beta$-cells and thereby opens voltage-dependent $\mathrm{Ca}^{2+}$ channels. The resulting rise in cytoplasmic calcium triggers exocytosis of insulin-containing granules $^{2}$.

The $\mathrm{K}_{\mathrm{ATP}}$-dependent mechanism for glucose-stimulated insulin secretion is well established, not least by phenotypes resulting from loss- and gain-of-function mutations in either component (Kir6.2 (encoded by KCNJ11) and SUR1 (encoded by ABCC8)) of the $\beta$-cell $\mathrm{K}_{\mathrm{ATP}}$ channel $^{2}$. However, there may be additional signal transduction cascades controlling insulin secretion ${ }^{3}$, as deduced e.g. from glucose-induced insulin secretion in SUR1 or Kir6.2 knock-out (KO) mice ${ }^{4-6}$. Not only the inhibition of $\mathrm{K}^{+}$channels, but also the opening of $\mathrm{Cl}^{-}$channels may depolarize $\beta$-cells ${ }^{3,7-9}$. Opening of $\mathrm{Cl}^{-}$channels leads to a depolarizing $\mathrm{Cl}^{-}$efflux because $\beta$-cells accumulate $\mathrm{Cl}^{-}$above equilibrium ${ }^{9-12}$ using $\mathrm{Na}^{+} \mathrm{K}^{+} 2 \mathrm{Cl}^{-}$cotransporters ${ }^{13,14}$.

It has been proposed that the volume-regulated anion channel VRAC contributes to insulin secretion by depolarizing $\beta$-cells in response to glucose-induced cell swelling ${ }^{7,15}$. VRACs (also known as VSOR or VSOAC) appear to be ubiquitously expressed in vertebrate cells. They mediate volume-activated $I_{\mathrm{Cl} \text {,vol }}$ anion currents that are crucial for regulatory volume decrease (RVD) after hypotonic cell swelling ${ }^{16,17}$. Swelling of pancreatic $\beta$-cells indeed induces $I_{\mathrm{Cl} \text {,vol-like currents }}{ }^{18}$, but the reported $\mathrm{Cl}^{-}>\mathrm{I}^{-}$ selectivity of those currents ${ }^{19,20}$ differs from canonical VRAC ${ }^{17}$. Since the molecular composition of VRAC has been enigmatic until recently ${ }^{21}$, attempts to demonstrate a role of VRAC in $\beta$-cells were based on notoriously non-specific inhibitors ${ }^{22-24}$ precluding conclusive evidence for an involvement of VRAC in glucose sensing or insulin secretion.

We recently identified LRRC8 heteromers as the molecular correlate of VRAC ${ }^{25}$. LRRC8A is the only essential subunit ${ }^{25,26}$, but needs at least one of the other LRRC8 (leucine-rich repeat containing 8) isoforms (LRRC8B,-C,-D or -E) to form volumeregulated plasma membrane channels ${ }^{25}$. The LRRC8 subunit composition determines not only biophysical properties of VRAC such as inactivation and single-channel conductance $25,27,28$, but more importantly its substrate specificity ${ }^{29,30}$. For instance, VRACs containing LRRC8A and -D subunits conduct various organic compounds including taurine, neurotransmitters, and other signaling molecules ${ }^{29,30}$, suggesting the intriguing possibility that VRAC has a role in paracrine or autocrine signaling.

We now generated a mouse model in which we disrupted the essential VRAC subunit LRRC8A specifically in pancreatic $\beta$-cells. $\beta$-cell swelling, induced by hypotonicity or glucose, activates canonical, LRRC8A-dependent $I_{\mathrm{Cl} \text {,vol }}$ currents that depolarize the cell. Glucose-induced intracellular $\mathrm{Ca}^{2+}$ responses are markedly delayed, but not abolished, in VRAC-deficient $\beta$ cells. First-phase glucose-induced insulin secretion by LRRC8Adeficient islets is reduced in vitro, and impaired glucose tolerance of $\beta$-cell-specific Lrrc8a KO mice suggests an important modulatory role of VRAC in insulin secretion in vivo.

\section{Results}

Expression and ablation of LRRC8/VRAC channels in $\beta$-cells. To analyze the role of volume-regulated VRAC anion channels in $\beta$-cell function and serum glucose regulation, we generated mice in which the essential VRAC subunit LRRC $8 A^{25,26}$ was specifically deleted in pancreatic $\beta$-cells. $\operatorname{Lrc} 8 a^{\text {lox/lox }}$ mice, in which protein-coding exon 3 is flanked by loxP sites (Supplementary Fig. 1), were crossed with Ins-Cre mice that express the Crerecombinase under the control of the rat insulin 2 promoter ${ }^{31}$.

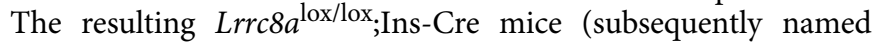
$\beta c-\Delta 8 \mathrm{a}$ mice for simplicity) were viable and lacked an overt phenotype.

Western blot analysis revealed that whole pancreas and purified islets expressed all five VRAC subunits (LRRC8A through LRRC8E) (Fig. 1a). In comparison to whole pancreas, however, islets had very little LRRC8E, but expressed larger amounts of LRRC8A, -C and -D (Fig. 1a). For comparison, human pancreatic islets express all LRRC8 subunits as determined by single-cell transcriptome profiling ${ }^{32}$. Although these data are difficult to compare, human LRRC8E appears less expressed in islets compared to exocrine pancreas as found here for mice, but human LRRC8C or -D expression does not seem to differ greatly between islets and acinar/ductal cells $^{32}$. Since we lacked antibodies suitable for detecting LRRC8 subunits in immunohistochemistry, we used knock-in mice expressing an epitope-tagged version of LRRC8D under its endogenous promoter to explore its presence in islets. LRRC8D, which is crucial for VRAC's ability to transport organic compounds ${ }^{29,30}$, was strongly expressed in insulin-containing $\beta$-cells (Fig. 1b, top). Immunolabeling of LRRC8D-tdTomato stained not only the plasma membrane, but also prominently the cytoplasm of these cells (Fig. 1b). However, we cannot be sure whether this represents a significant presence of native LRRC8D-containing VRACs in intracellular organelles, or rather may have been caused by the fusion of the large epitope to the LRRC8D carboxy-terminus. LRRC8D was also found, albeit at apparently lower levels, in glucagon-secreting a-cells (Fig. 1b, bottom). Consistent with the large preponderance of exocrine over endocrine tissue, pancreatic expression levels of LRRC8A appeared unchanged between control ( $\left.\operatorname{rrc} 8 a^{\text {lox/lox }}\right)$ and $\beta c-\Delta 8 \mathrm{a}$ mice (Fig. 1c). By contrast, LRRC8A protein levels were markedly decreased in $\beta c-\Delta 8 \mathrm{a}$ islets (Fig. 1c). The magnitude of this decrease $(\sim 65 \%)$ was roughly compatible with a complete disruption of $\operatorname{Lrc8} a$ in $\beta$-cells (constituting $\sim 75 \%$ of rodent islets ${ }^{33}$ ) if all islet cells express similar amounts of LRRC8A. Indeed, lacZ staining of islets from mice expressing $\beta$-galactosidase under the control of the $L r r c 8 a$ promoter (Fig. 1d) suggested that all islet cells express similar levels of LRRC8A.

Islet morphology of adult $\beta c-\Delta 8 \mathrm{a}$ mice appeared normal (Fig. 1e) and immunohistochemistry did not reveal changes in insulin or glucagon expression (Fig. 1f). Western blot of pancreas extracts suggested similar insulin levels (Fig. 1c), a finding confirmed by ELISA analysis (Fig. $1 \mathrm{~g}$ ). $\beta$-cell-specific disruption of LRRC8A neither changed total pancreatic (Fig. 1h) nor $\beta$-cell mass (Fig. 1i). We neither detected changes in the abundance of Kir6.2 (Fig. 1c), the ion-conducting $\alpha$-subunit of the pivotal $K_{\mathrm{ATP}}$ channel, nor did we detect signs for inflammation or increased activated caspase in $\beta c-\Delta 8$ a pancreas (Supplementary Fig. 2). Hence neither developmental or degenerative changes, nor indications for altered $\mathrm{K}_{\mathrm{ATP}^{-}}$ dependent glucose signaling were detected in $\beta c-\Delta 8 \mathrm{a}$ pancreas. Moreover, $\beta c-\Delta 8$ a mice showed no increased lethality during our observation period of 30 weeks and their weight developed normally during that time (Fig. $1 \mathrm{j}$ ). 

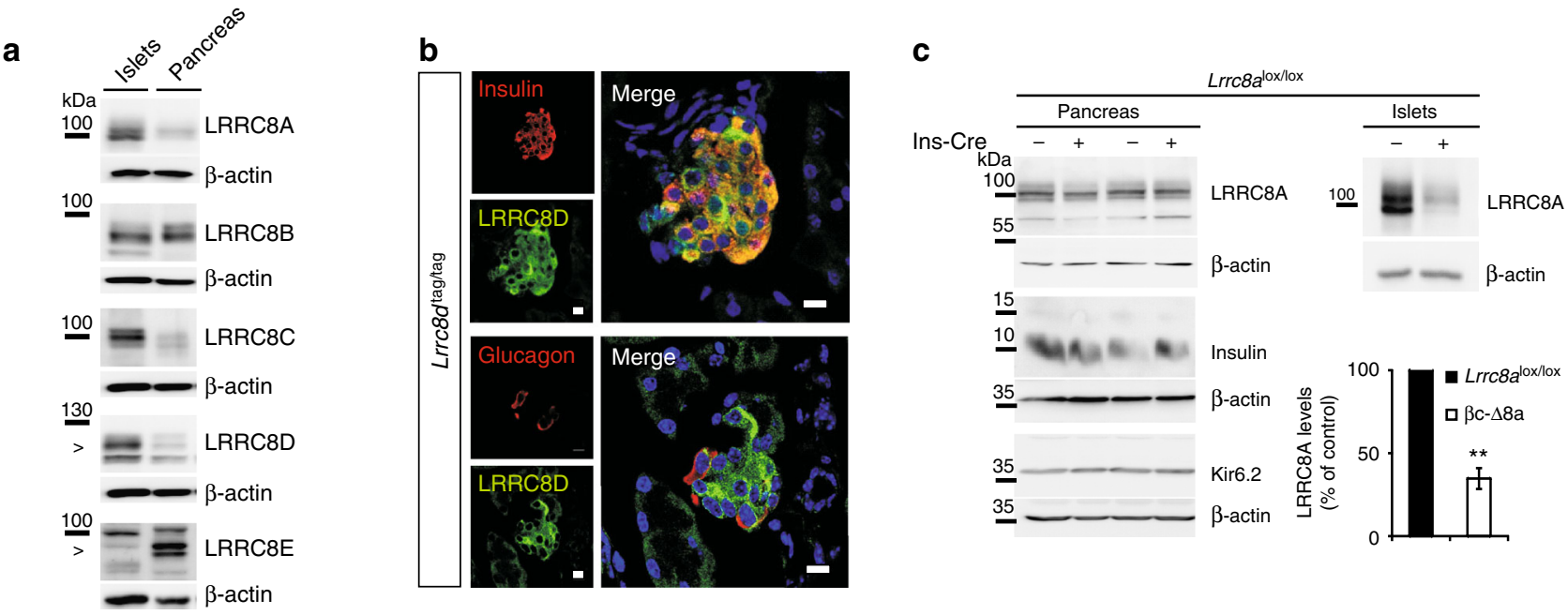

d

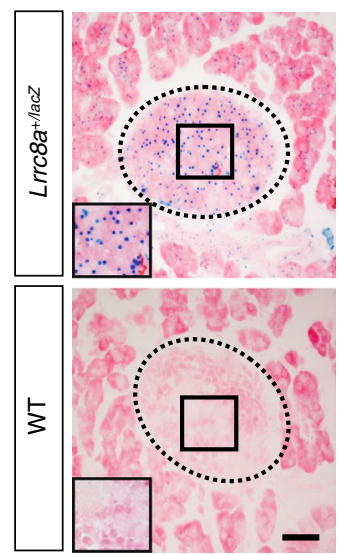

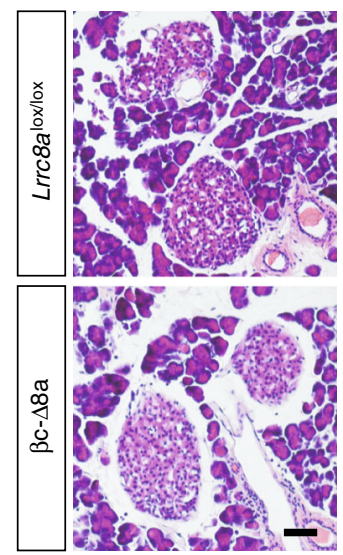

f

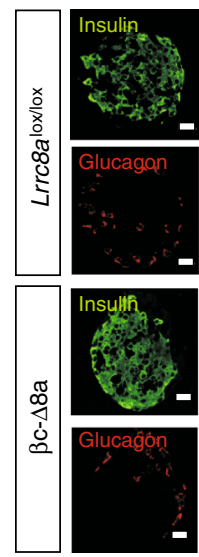

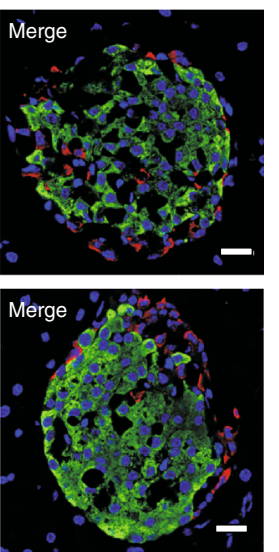

g

- Lrrc8alox/lox $\square \mathrm{c}-\Delta 8 \mathrm{a}$
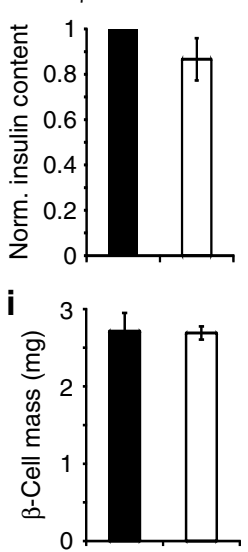

h
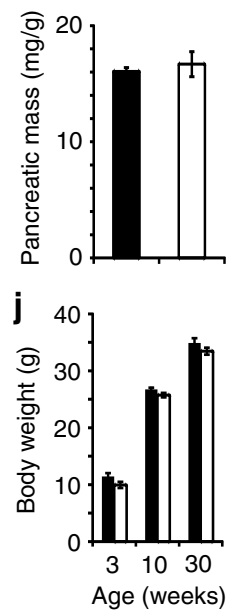

Fig. 1 LRRC8 proteins in the pancreas and normal islet morphology upon $\beta$-cell-specific Lrrc8a disruption. a Western blot detection of the five VRAC subunits LRRC8A, $-B,-C,-D$, and $-E$ in lysates of purified islets of Langerhans (left lanes) or total pancreas (right) from wild-type mice. $\beta$-actin, loading control. Arrowheads highlight specific bands as determined by previous knock-out controls. $\mathbf{b}$ Immunofluorescent detection (green) of LRRC8D in pancreatic sections from knock-in mice expressing a LRRC8D-tdTomato fusion protein, co-stained (in red) for insulin (above) or glucagon (below). Left panels, individual channels; right panels, overlays, with co-localization yielding yellow. Note that $\beta$-cells express much more LRRC8D than the surrounding

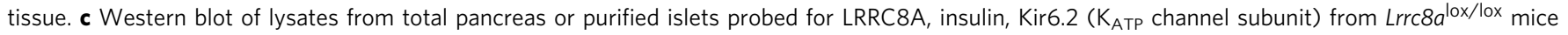
lacking Cre expression (-) or expressing Cre specifically in $\beta$-cells $(+) . \beta$-actin, loading control. Right bottom, quantification of LRRC8A expression in pancreatic islets normalized to $\operatorname{Lrc} 8^{\text {lox } / \text { lox }}$ control. $N=3$ independent experiments. Error bars, mean \pm SEM. ${ }^{\star \star} P<0.01$ (Student's $t$-test). d Lrrc $8 a$ promoter-driven $\beta$-gal expression (X-gal staining, blue dots) in islets. Dotted lines highlight islets of Langerhans, insets higher magnification of boxed area. Cells co-stained with eosin $Y$ (pink). e Hematoxylin/eosin (H\&E) stained formalin-fixed pancreatic sections of control (Lrrc8alox/lox ) or $\beta c-\Delta 8 a$ mice (lacking LRRC8A in $\beta$-cells). f Immunofluorescent staining of pancreatic islets of $L$ rrc $8 a^{\text {lox } / l o x}$ and $\beta c-\Delta 8 a$ animals for insulin (green) and glucagon (red), respectively. $\mathbf{g}$ Insulin levels of whole pancreas lysates normalized to control ( $\operatorname{rrc} 8 a^{\text {lox } / l o x}$ ). $\mathbf{h}$ Pancreatic mass of $\operatorname{Lrrc} 8 a^{\text {lox } / \text { lox }}$ and $\beta c-\Delta 8 \mathrm{a}$ animals determined as ratio of organ to body weight. $\mathbf{i} \beta$-cell mass as defined as ratio of insulin-positive cell area to complete pancreatic tissue area, multiplied by pancreatic weight. $\mathbf{j}$ Body weight of $L r r 8 a^{\text {lox/lox }}$ (black bars) and $\beta c-\Delta 8 \mathrm{a}$ animals (white bars) at 3, 10 and 30 weeks of age. g-j Mean values $\pm S E M$ are shown. Differences between genotypes are not significant in unpaired $t$-test: $\mathbf{g} p=0.185, n=7 ; \mathbf{h} p=0.609, n=3 ; \mathbf{i} p=0.968, n=6$. j $p=0.086$ at 3 weeks, $p=0.05$ at 10 weeks, and $p=0.214$ at 30 weeks, $n=16\left(\operatorname{Lrc} 8 a^{\text {lox } / \text { lox }}\right), n=11(\beta c-\Delta 8$ a). Scale bars in b: $10 \mu \mathrm{m}$, in $\mathbf{d}-\mathbf{f}: 50 \mu \mathrm{m}$

Hypotonicity and glucose elicit LRRC8/VRAC currents in $\beta$ cells. Exposure of both control $\left(\operatorname{Lrc} 8 a^{\text {lox/lox }}\right)$ and $\beta c-\Delta 8 \mathrm{a} \beta$-cells to a hypotonic solution led to similar levels of cell swelling, but $\beta$ cells with disrupted $\operatorname{Lrc} 8 a$ lacked the typical slow RVD that was visible in control cells (Fig. 2a). Whole-cell patch-clamp recordings from control $\beta$-cells revealed the slow development of outwardly rectifying $\mathrm{Cl}^{-}$currents $\left(I_{\mathrm{Cl}, \mathrm{vol}}\right)$ upon exposure to hypotonic medium (Fig. 2b). These currents were almost completely blocked by $20 \mu \mathrm{M}$ DCPIB, a potent, but non-specific inhibitor of VRACs ${ }^{34-37}$ (Fig. 2b) and were absent from $\beta c-\Delta 8 \mathrm{a}$ $\beta$-cells (Fig. $2 c-e$ ). As described previously ${ }^{19,20,23}$, these currents displayed only weak inactivation at positive potentials (Fig. $2 \mathrm{~d}$ ), a finding we can now attribute to the relatively low expression of the inactivation-promoting subunit $L R R C 8 \mathrm{E}^{25,28}$ in islets (Fig. 1a). Two previous reports stated that $I_{\mathrm{Cl}, \mathrm{vol}}$ of $\beta$-cells displays a $\mathrm{Cl}^{-}>\mathrm{I}^{-}$selectivity ${ }^{19,20}$. This fueled speculation that the $\beta$-cell channel differs from canonical VRAC ${ }^{38}$. Since the strict dependence of $I_{\mathrm{Cl}, \mathrm{vol}}$ on LRRC8A now identified the channel as 
a

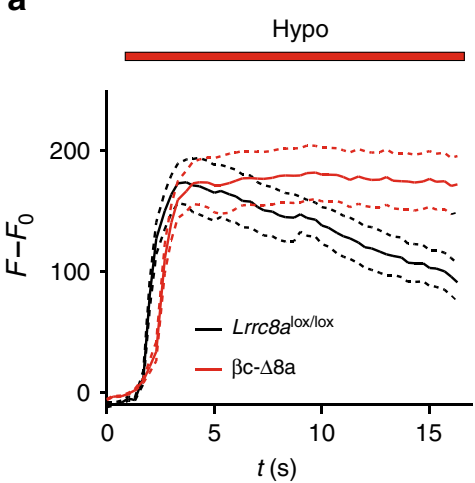

d

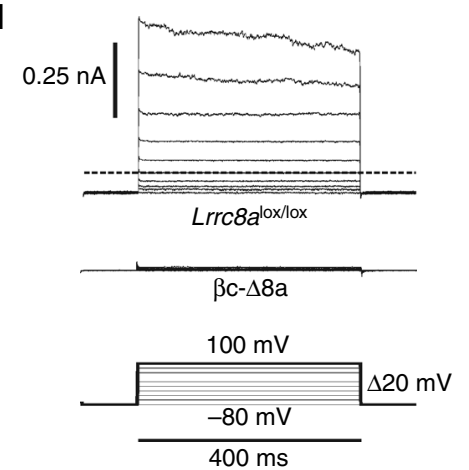

b

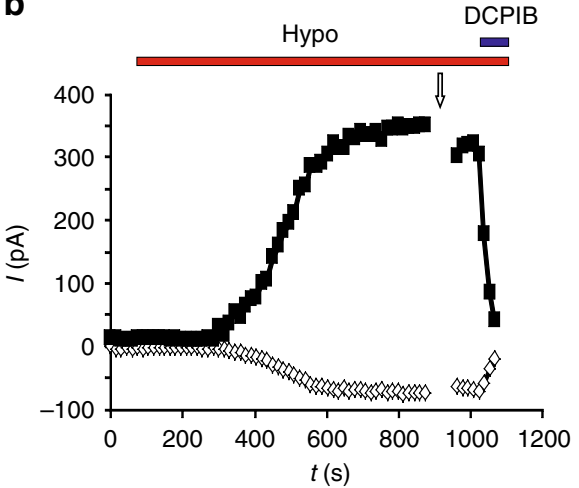

e

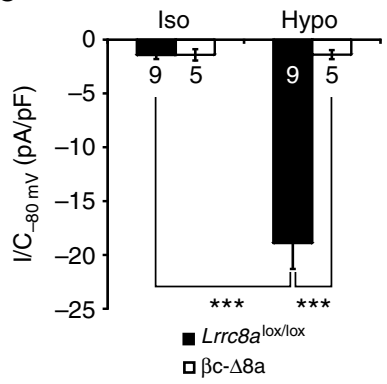

c
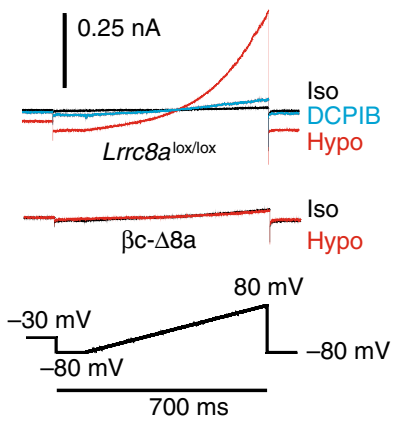

f

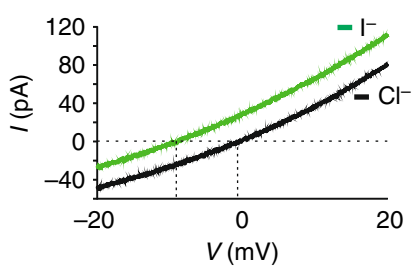

Fig. 2 Hypotonicity-induced cell swelling and VRAC currents in mouse $\beta$-cells. a Cell volume as monitored in individual $\beta$-cells using calcein fluorescence. The extracellular isotonic solution was replaced by a $30 \%$ hypotonic solution $(210 \mathrm{mOsm}$ ) during the time indicated by the bar. Averaged curves \pm SEM (dotted lines), $n=16$ and $n=18$ for $\operatorname{Lrc} 8 a^{\text {lox } / l o x}$ and $\beta c-\Delta 8 a$-cells, respectively. Data are representative of three independent experiments. $\mathbf{b}$

Representative time course of $I_{\mathrm{Cl}, \text { vol }}$ of an isolated primary $\beta$-cell provoked by superfusion with hypotonic solution ( $\left.240 \mathrm{mOsm}\right)$ without or with $20 \mu \mathrm{M}$ DCPIB as indicated. Currents elicited at -80 to $80 \mathrm{mV}$ by voltage ramps (see c) are plotted. c Typical current-voltage (I-V) curves of hypotonicityprovoked $I_{\mathrm{Cl}, \text { vol }}$ elicited by the ramp protocol shown below, from indicated genotypes and conditions. $\mathbf{d}$ Representative current traces obtained with the voltage step protocol shown at bottom. The upper traces show control ( $\operatorname{rrc} 8^{\text {lox}} /$ lox $)$ currents after full activation of $I_{\mathrm{Cl}, \text { vol, }}$, taken at the time indicated by arrow in $\mathbf{b}$. Even at $+100 \mathrm{mV}, \beta$-cell $I_{\mathrm{Cl}, \text { vol }}$ only slightly inactivates. The lower traces are from a $\beta c-\Delta 8$ a $\beta$-cell exposed for 15 min to hypotonicity. e $I_{C I, v o l}$ current densities at $-80 \mathrm{mV}$ of $\operatorname{Lrc} 8 a^{\text {lox/lox }}$ and $\beta c-\Delta 8 \mathrm{a} \beta$-cells under iso- and hypotonic conditions. Mean values $\pm \mathrm{SEM}$; ${ }^{\star \star \star} p<0.0005$ (one-way ANOVA, Tukey's test); number of cells given in bars; iso: isotonic solution ( $310 \mathrm{mOsm})$, hypo: hypotonic solution $(240 \mathrm{mOsm})$. f lon selectivity of $\beta$-cell $I_{\mathrm{Cl} \text {,vol }}$. Example traces (from the same cell) obtained with the ramp protocol after maximal $I_{\mathrm{Cl}, \text { vol }}$ activation, in the presence of extracellular chloride (black trace) or iodide (green trace). The shifts of reversal potentials $E_{\text {rev }}$ with $I^{-}$to more negative values indicated a permeability ratio $\mathrm{pl}^{-} / p \mathrm{Cl}^{-}=1.44 \pm 0.06(n=6)$

canonical VRAC (i.e., as LRRC8 channel), we re-investigated this issue (Fig. 2f) and found that $\beta$-cell $I_{\mathrm{Cl}, \text { vol }}$ displays the $\mathrm{I}^{-}>\mathrm{Cl}^{-}$ selectivity that is typical for VRACs ${ }^{17,25,39}$.

Exposure of $\beta$-cells to high extracellular glucose also activates an outwardly rectifying $\mathrm{Cl}^{-}$current, which shares several characteristics with $I_{\mathrm{Cl}, \text { vol }} 19,20,23$. This activation has been tentatively attributed to $\beta$-cell swelling that is observed after exposure to high extracellular glucose ${ }^{15,40}$ and that may be caused by osmotic effects of intracellular glucose metabolites $70-42$. Indeed, when increasing the glucose concentration of the isotonic superfusate from 3 to $25 \mathrm{mM}$, cell swelling was observed in both Lrrc8alox/lox and $\beta c-\Delta 8$ a $\beta$-cells (Fig. 3a). The extent of swelling was smaller than with large changes of extracellular osmolarity (Fig. 2a) and did not differ significantly between the genotypes. Exposure to $20 \mathrm{mM}$ glucose elicited typical outwardly rectifying, slightly inactivating and DCPIB-sensitive currents in control $\beta$-cells (Fig. 3b, c) that were abolished in $\beta c-\Delta 8$ a cells (Fig. $3 c$, d). Hence both hypotonicity- and glucose-induced $\beta$-cell currents are mediated by swelling-activated LRRC8/VRAC channels.

Loss of LRRC8A reduces glucose response of $\beta$-cells. We next investigated the impact of VRAC on $\beta$-cell excitation using the perforated patch-clamp technique in the current clamp mode (at
$I=0$ ). This allows recordings of the membrane potential with minimal effects on cellular metabolism or ion concentrations. Consistent with VRAC being closed at resting conditions ${ }^{17,39}$ (Fig. 2b), the resting membrane potential did not differ between Lrrc $8 a^{\text {lox } / \text { lox }}$ and $\beta c-\Delta 8$ a $\beta$-cells, neither at 1 nor at $5 \mathrm{mM}$ external glucose (Fig. 4a). When exposed to external hypotonicity (220 mOsm), $\beta$-cells from $\operatorname{Lrc} 8 a^{\text {lox/lox }}$, but not from $\beta c-\Delta 8$ a mice, slowly depolarized (Fig. 4b-d), presumably by an efflux of $\mathrm{Cl}^{-}$ through LRRC8 channels, which activate under these conditions with a similarly slow time course (Fig. 2b). This depolarization was more pronounced at $5 \mathrm{mM}$ (Fig. $4 \mathrm{~b}, \mathrm{c}$ ) than at $1 \mathrm{mM}$ glucose (Fig. 4e, f). This difference can be explained by a partial inhibition of $\mathrm{K}_{\text {ATP }}$ at $5 \mathrm{mM}$ glucose. Although not sufficient to significantly depolarize $\beta$-cells when VRAC is closed or absent (in $\beta c-\Delta 8 \mathrm{a}$ cells) (Fig. 4a), this inhibition reduces the hyperpolarizing $\mathrm{K}^{+}$current that opposes the depolarizing $\mathrm{Cl}^{-}$current through VRAC. In a sizeable fraction of $L r r c 8 a^{\text {lox/lox }}$, but not $\beta c-\Delta 8 \mathrm{a}$ $\beta$-cells, hypotonicity elicited membrane potential spiking (Fig. 4g, h).

Increasing external glucose concentration from 1 to $15 \mathrm{mM}$ induced action potentials in both $L r r c 8 a^{\text {lox/lox }}$ and $\beta c-\Delta 8 \mathrm{a} \beta$-cells (Fig. 5a, b). However, cells devoid of VRAC needed on average $\sim 100 \mathrm{~s}$ longer to reach the spiking threshold, although this difference was not statistically significant with our sample size 
a

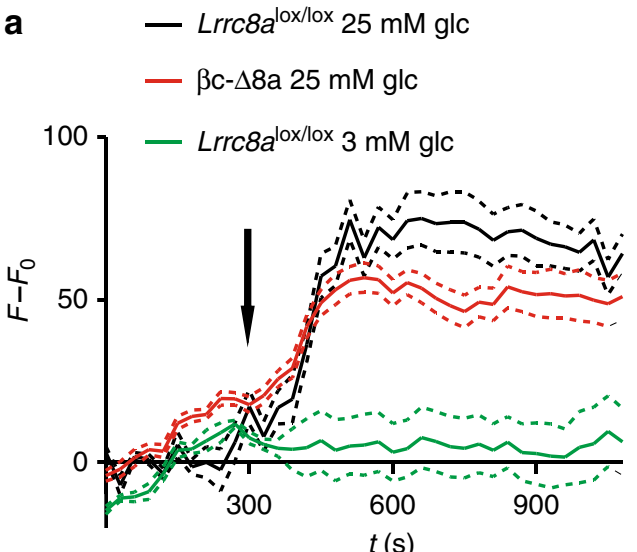

C

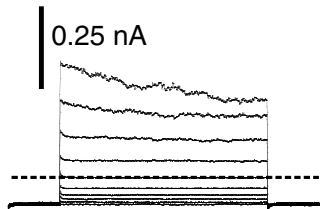

Lrrc8a $a^{\text {lox/lox }}$

$\beta c-\Delta 8 \mathrm{a}$ b
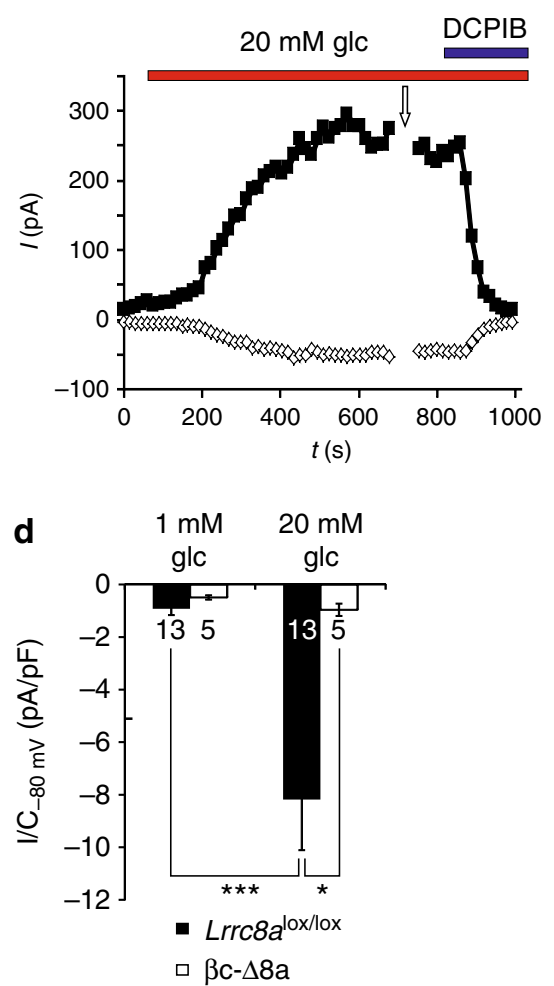

Fig. 3 Cell swelling and induction of LRRC8/VRAC currents in $\beta$-cells by high extracellular glucose. a Cell volume as monitored in individual $\beta$-cells loaded with calcein. Cell bath was switched from a $3 \mathrm{mM}$ to a $25 \mathrm{mM}$ glucose-containing isotonic solution at the time indicated by the arrow. Shown are mean values \pm SEM (dotted lines), $n=15$ and $n=23$ for $L$ rrc $8 a^{\text {lox/lox }}$ and $\beta c-\Delta 8$ a $\beta$-cells, respectively, and are representative of three independent experiments. Green trace corresponds to bath change without changing the glucose concentration, a control to exclude perfusion artefacts $(n=6)$. $\mathbf{b}$ Time course of anion current activation by superfusion with $20 \mathrm{mM}$ glucose in isotonic saline ( $310 \mathrm{mOsm})$. Application of $20 \mu \mathrm{M}$ DCPIB blocked the currents. Minimal and maximal currents elicited at -80 or $80 \mathrm{mV}$ by voltage ramps (as in Fig. $2 \mathrm{c}$ ) are plotted. c Representative current traces obtained after $>10$ min superfusion with $20 \mathrm{mM}$ glucose from the indicated genotypes. Currents were elicited by the voltage protocol shown in Fig. $2 \mathrm{~d}$. The upper traces show currents at the time indicated by the arrow in $\mathbf{b}$. $\mathbf{d} / \mathrm{Cl,vol}$ Current densities at $-80 \mathrm{mV}$ of $L$ rrc $8 a^{\text {lox }} /$ lox and $\beta \mathrm{c}-\Delta 8 \mathrm{a} \beta$-cells under indicated conditions. Mean currents $\pm \mathrm{SEM}$; ${ }^{\star} p<0.05 ;{ }^{* \star} p<0.0005$ (one-way ANOVA, Tukey's test); number of cells indicated in bars

(Fig. 5c). The frequency and amplitude of glucose-induced action potentials were unchanged (Fig. $5 \mathrm{~d}$ ). $\beta$-cells began to spike before they depolarized to the degree observed with hypotonicity (Fig. 4), presumably because the increased membrane resistance caused by partial $\mathrm{K}_{\mathrm{ATP}}$ closure renders the positive feedback between voltage-dependent $\mathrm{Na}^{+}$- and $\mathrm{Ca}^{2+}$-channel opening and depolarization more efficient. In contrast to glucose, which requires cellular uptake and metabolism to exert its inhibitory and stimulatory effects on $\mathrm{K}_{\mathrm{ATP}}$ and VRAC, respectively, the $\mathrm{K}_{\mathrm{ATP}}$ inhibitor tolbutamide almost instantly elicited $\beta$-cell spiking that was indistinguishable between the genotypes (Fig. 5a, b, e). This agrees with unchanged Kir6.2 protein expression (Fig. 1c) and suggests that the activity of this pivotal channel is not affected by the loss of VRAC. As another read-out for $\beta$-cell stimulation, we determined the rise of intracellular $\mathrm{Ca}^{2+}\left(\left[\mathrm{Ca}^{2+}\right]_{\mathrm{j}}\right)$, the final trigger for insulin exocytosis. Mirroring the effect on $\beta$-cell excitability, $15 \mathrm{mM}$ glucose increased $\left[\mathrm{Ca}^{2+}\right]_{\mathrm{i}}$ in both genotypes, but with a significantly longer delay in $\beta c-\Delta 8$ a cells (Fig. $5 f-h)$. A tendency for a delayed glucose response of $\operatorname{Lrc} 8 a^{-/}-\beta$-cells became already apparent in the $6-8 \mathrm{mM}$ glucose concentration range (Supplementary Fig. 3). The peak $\mathrm{Ca}^{2+}$-response, however, did not differ significantly between the genotypes (Fig. 5i). To investigate whether VRAC influences $\beta$-cell excitability beyond the initial $15 \mathrm{~min}$ investigated so far, we studied the effect of 10 $\mathrm{mM}$ glucose on $\mathrm{Ca}^{2+}$ oscillations of intact islets that were preincubated for $30 \mathrm{~min}$ with this glucose concentration before starting the measurements. Islets from both genotypes showed the typical range of $\mathrm{Ca}^{2+}$ oscillation patterns ${ }^{43}$ (Supplementary Fig. 4), with no obvious difference between the genotypes. To conclude, although VRAC is not required for glucose to excite $\beta$ cells, it increases their glucose sensitivity during the early phase of glucose stimulation.

Lrrc8a disruption reduces insulin secretion. We next asked whether VRAC modulates insulin secretion. Supernatants from single islets from $L r r c 8 a^{\text {lox/lox }}$ and $\beta c-\Delta 8$ a mice were collected 30 min after stimulation and their insulin content determined by ELISA (Fig. 6a). There was no difference in insulin release between the genotypes in the presence of $3.3 \mathrm{mM}$ glucose. Depolarization of $\beta$-cells by increasing $\left[\mathrm{K}^{+}\right]_{\mathrm{o}}$ from 5 to $45 \mathrm{mM}$, or by exposure to $300 \mu \mathrm{M}$ tolbutamide, increased insulin secretion about 15- and 5-fold, respectively, irrespective of the $\operatorname{Lrc} 8 \mathrm{a}$ genotype. Increasing glucose concentration to $25 \mathrm{mM}$ enhanced insulin release about eightfold and sixfold with $\operatorname{Lrc} 8 a^{\text {lox/lox }}$ and $\beta c-\Delta 8 \mathrm{a}$ islets, respectively. However, this apparent difference failed to reach statistical significance $(p=0.11)$. A similar degree of stimulation and borderline difference between the genotypes $(p=0.08)$ was observed when islets were exposed to both $25 \mathrm{mM}$ glucose and $300 \mu \mathrm{M}$ tolbutamide. The absence of a marked effect 
a

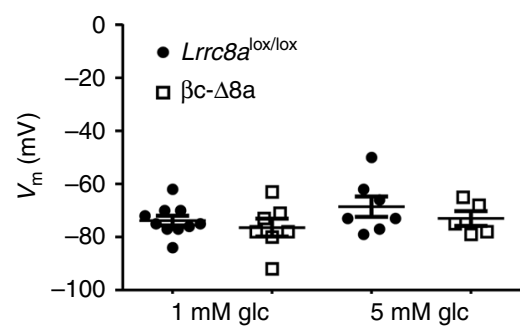

c

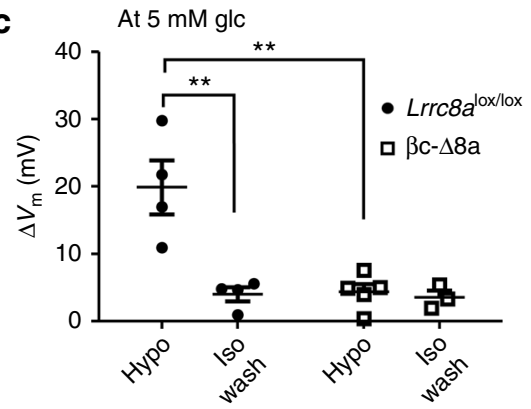

e

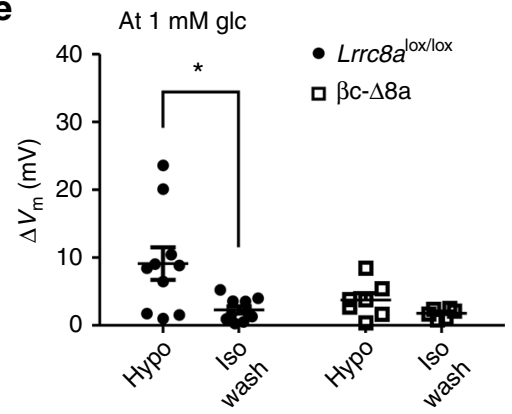

b

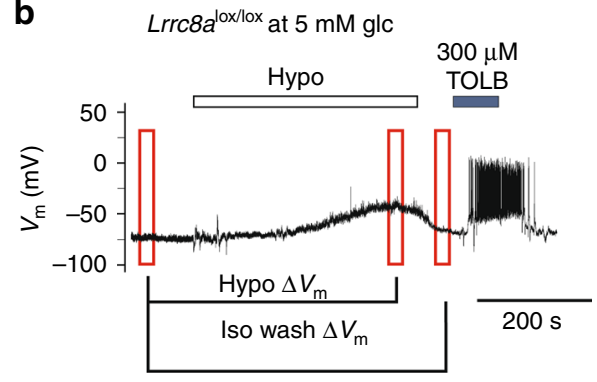

d

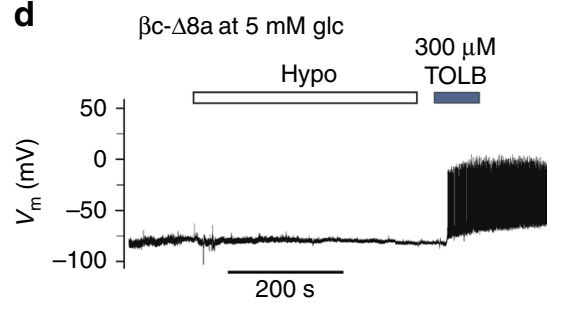

f

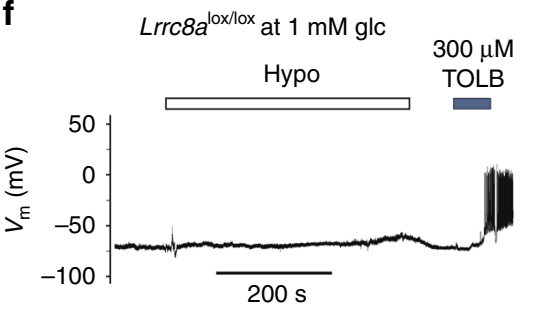

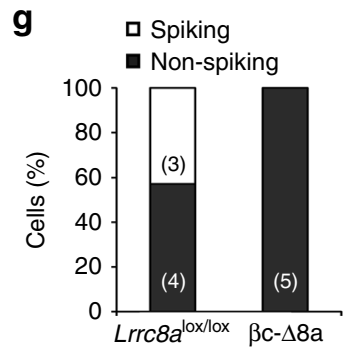

h

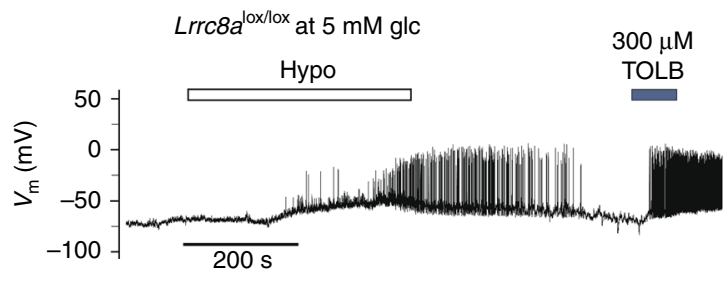

Fig. 4 Hypotonicity-induced depolarization of $\beta$-cells. Gramicidin-perforated patch-clamp recordings of primary mouse $\beta$-cells. a Resting membrane potential of control $\operatorname{Lrc} 8 \mathrm{a}^{\text {lox/lox }}$ or $\beta c-\Delta 8 \mathrm{a} \beta$-cells at 1 or $5 \mathrm{mM}$ glucose concentrations. Mean values \pm SEM indicated by error bars. $\mathbf{b}$ Representative trace for hypotonicity-induced depolarization of the membrane potential $V_{m}$ in control $L r r c 8 a^{\text {lox/lox }}$ animals at $5 \mathrm{mM}$ glucose. TOLB, tolbutamide. $\mathbf{c} \Delta V_{\mathrm{m}}$ after applying hypotonicity, or following washout with isotonic solution of $L \mathrm{rrc} 8 \mathrm{a}^{\text {lox} / \mathrm{lox}}$ or $\beta c-\Delta 8$ a cells at $5 \mathrm{mM}$ glucose, calculated from data as indicated in $\mathbf{b}$. Spiking cells (see $\mathbf{g}$ and $\mathbf{h}$ ) were excluded from analysis. $\mathbf{d}$ Representative voltage trace showing lack of hypotonicity-induced depolarization of $\beta c-\Delta 8$ a $\beta$ cells at $5 \mathrm{mM}$ glucose. e $\Delta V_{\mathrm{m}}$ of $L \mathrm{rrc} 8 a^{\text {lox } / \text { lox }}$ or $\beta c-\Delta 8$ a cells as in $\mathbf{c}$, but at $1 \mathrm{mM}$ glucose. $\mathbf{f}$ Representative trace for $\operatorname{Lrc} 8 a^{\text {lox } / \text { lox }} \beta$-cells challenged with hypotonicity in the presence of $1 \mathrm{mM}$ glucose. $\mathbf{g}$ Percentage of cells responding with electrical activation following hypotonic stimulation. $\mathbf{h}$ Voltage trace of an $\operatorname{Lrc} 8 a^{\text {lox/lox }} \beta$-cell responding with electrical activity to hypotonicity in the presence of $5 \mathrm{mM}$ glucose. ${ }^{\star} p<0.05$, ${ }^{\star \star} p<0.01$ (one-way ANOVA, Tukey's test)

of VRAC ablation on insulin secretion agrees with the limited effect on glucose-induced excitation and $\mathrm{Ca}^{2+}$-transients of $\beta$ cells, which was apparent only in a 5-10 min time window (Fig. 5c, f-h, Supplementary Fig. 3). Indeed, when measured only within the first $8 \mathrm{~min}$ of adding $25 \mathrm{mM}$ glucose, $\operatorname{Lrc} 8 \mathrm{a}^{\text {lox/lox }}$ islets secreted about twice as much insulin than their $\beta c-\Delta 8$ a counterparts $(p=0.008)$ (Supplementary Fig. 5). However, these high glucose concentrations are unlikely to be reached in vivo. We therefore examined whether VRAC modulates insulin secretion with more physiological glucose stimuli, which was suggested by the effect of $15 \mathrm{mM}$ (Fig. $5 \mathrm{a}-\mathrm{c}, \mathrm{f}-\mathrm{h}$ ) and possibly even lower (Supplementary Fig. 3) glucose concentrations on $\beta$-cell excitability. Indeed, a significant, roughly $50 \%$ decrease of insulin secretion by $\beta c-\Delta 8 \mathrm{a}$ islets in an 8 min time window was observed also with $10 \mathrm{mM}$ glucose (Fig. 6b). There was no difference in the response to tolbutamide or high potassium under identical conditions, confirming that canonical $\mathrm{K}_{\mathrm{ATP}}$ signaling is not affected (Fig. 6b). We finally tested whether the deletion of VRAC in $\beta$ - 
cells affects the regulation of blood glucose in vivo. Whereas serum concentrations of glucose were not different between the genotypes $\left(L r r c 8 a^{\text {lox} / l o x}, 163 \pm 12 \mathrm{mg} / \mathrm{dl} ; \beta \mathrm{c}-\Delta 8 \mathrm{a}, 162 \pm 9 \mathrm{mg} / \mathrm{dl} ; n\right.$ $=11), \beta \mathrm{c}-\Delta 8 \mathrm{a}$ mice were abnormal in glucose tolerance assays (Fig. 6c). Mice of both genotypes were injected intraperitoneally with glucose solutions and their blood glucose levels were followed over $2 \mathrm{~h}$. Compared to $\operatorname{Lrc} c \mathrm{a}^{\text {lox } / \text { lox }}$ control mice, $\beta \mathrm{c}-\Delta 8 \mathrm{a}$ mice displayed significantly higher serum glucose concentrations
30 and 60 min after the glucose load. By contrast, mice of either genotype behaved similarly in insulin tolerance tests (Fig. 6d), demonstrating that $\beta$-cell-specific disruption of VRAC, as expected, does not influence peripheral glucose uptake. Impor-

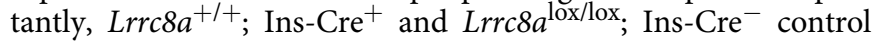
groups behaved indistinguishably in these assays, showing that a reported interference of the Ins2-Cre construct itself ${ }^{44}$ is not of concern here. Finally, glucose-stimulated insulin secretion in vivo a

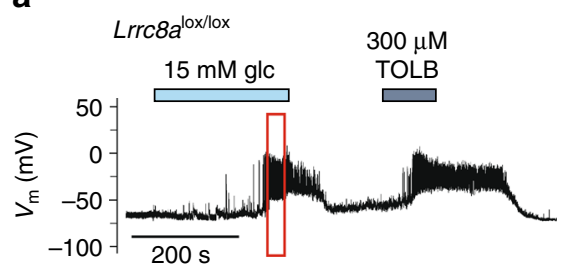

c

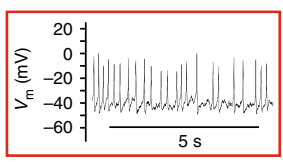

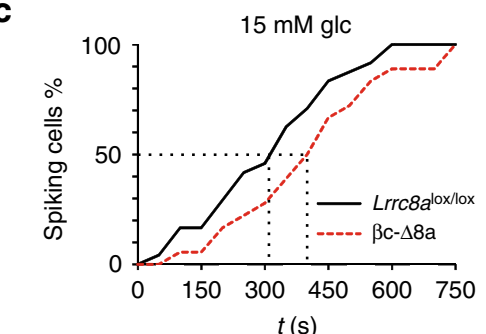

$t(\mathrm{~s})$

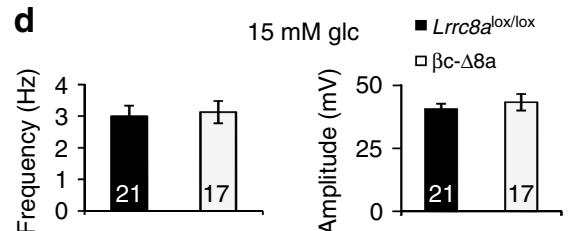

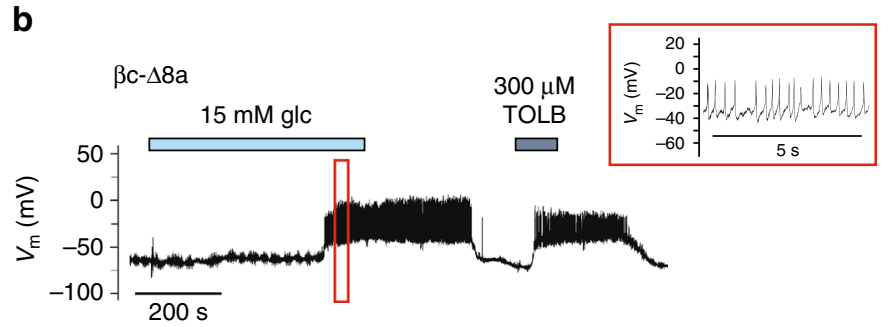

b

f

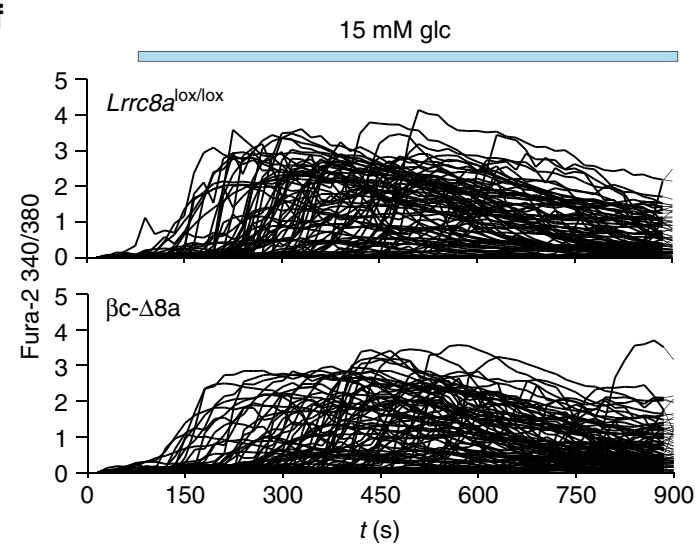

g

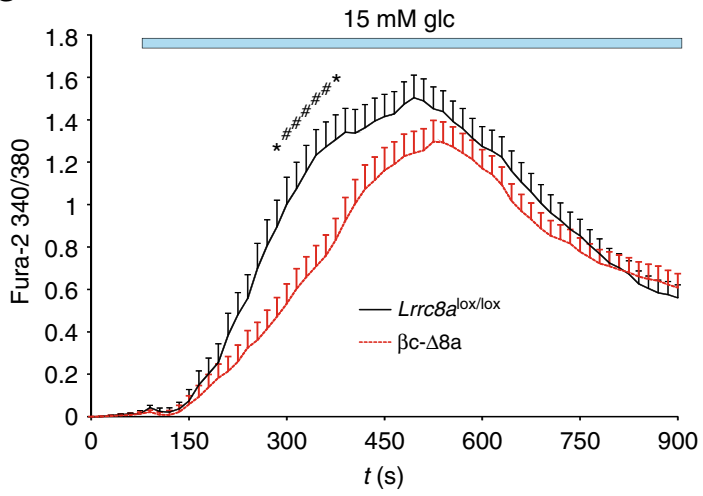

h

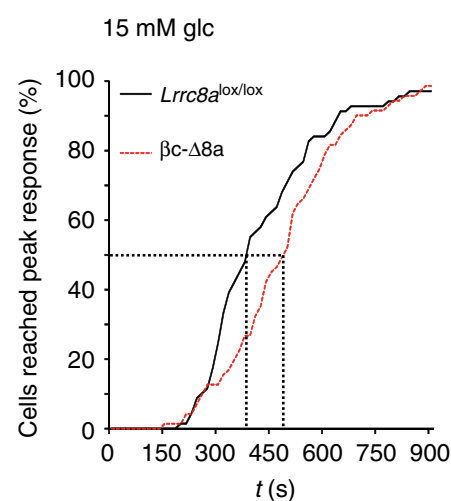

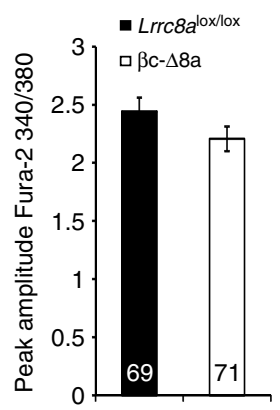

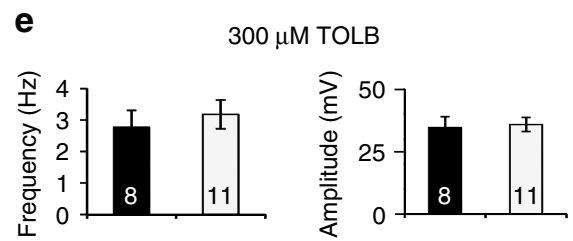

i 
Fig. 5 Glucose-induced electrical activity and intracellular $\mathrm{Ca}^{2+}$ response in $L r r c 8 a^{\text {lox } / l o x}$ and $\beta c-\Delta 8 a$ cells. $\mathbf{a}$, b Representative voltage traces for glucoseand tolbutamide-induced electrical activity of control $L r r c 8 a^{\text {lox } / l o x}(\mathbf{a})$ and $\beta c-\Delta 8$ a (b) $\beta$-cells obtained with gramicidin-perforated patches in the current clamp mode. Enlarged traces are shown in red boxes, with corresponding time periods indicated by boxes in the complete trace at left. c Percentage of electrically active cells plotted against time after glucose application. The response of $\beta c-\Delta 8 \mathrm{a}$ cells seemed delayed by about $100 \mathrm{~s}$ (dotted lines), but the difference between genotypes failed to be statistically significant with 24 control and $18 \beta c-\Delta 8 \mathrm{a} \beta$-cells. $\mathbf{d}$ Mean frequency and amplitude of spikes during bursts of action potentials elicited by $15 \mathrm{mM}$ glucose. e Mean frequency and amplitude of spikes elicited by $300 \mu \mathrm{M}$ tolbutamide. $\mathbf{f}$ Individual traces for Fura- 2 fluorescence ratios elicited by excitation at $\lambda=340$ and $380 \mathrm{~nm}$ (indicative of $\left[\mathrm{Ca}^{2+}\right]_{\mathrm{i}}$ ). $15 \mathrm{mM}$ glucose was added at $t=60 \mathrm{~s}$. $\mathbf{g}$ Mean ratio of Fura2 fluorescence over time. Time points at which differences between the two genotypes reached statistical significance are indicated. ${ }^{\star} p<0.05,{ }^{\#} p<0.01$ (two-way ANOVA, Bonferroni multiple comparisons); mean values $\pm \mathrm{SEM}, 69$ control and $71 \beta \mathrm{c}-\Delta 8 \mathrm{a} \beta$-cells. $\mathbf{h}$ Cumulative plot of cells that have reached peak levels of $\left[\mathrm{Ca}^{2+}\right]_{i}$ after addition of $15 \mathrm{mM}$ glucose as function of time. The difference is statistically significant $(p=0.005, \mathrm{Kolmogorov}-\mathrm{Smirnov}$ test). $\mathbf{i}$ Peak value of calcium response of $\beta$-cells of both genotypes. The difference is not significant. Number of cells indicated in columns
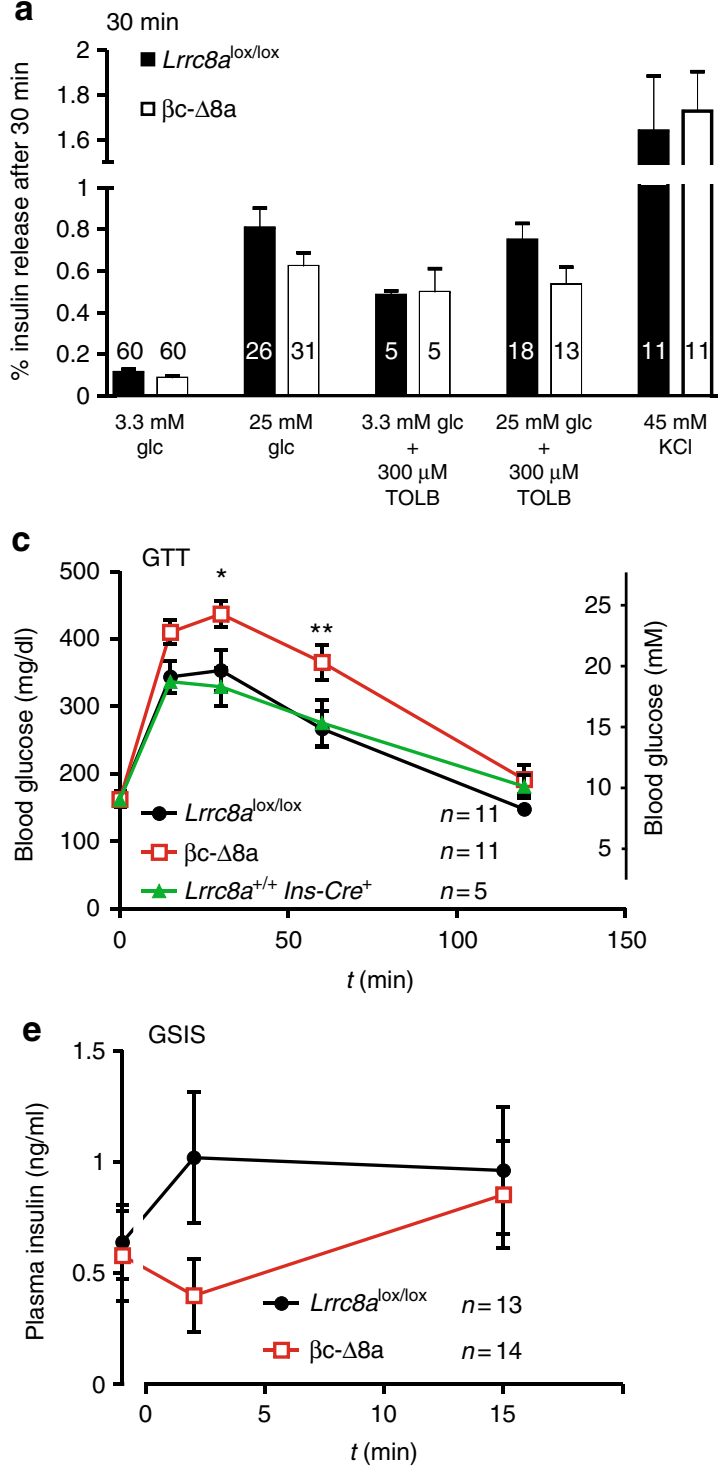
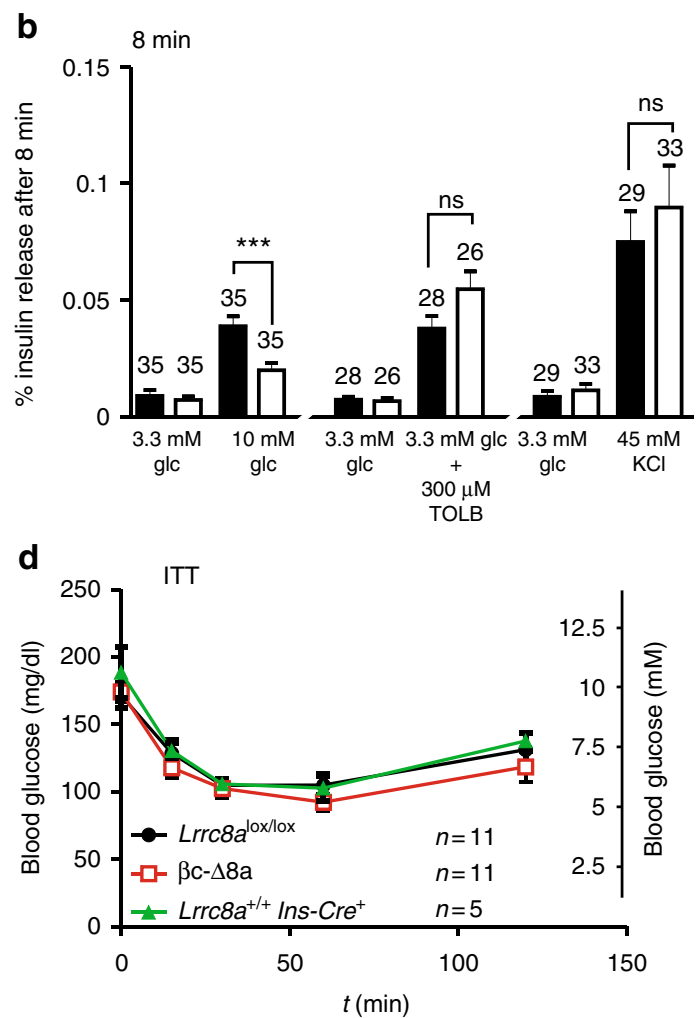

Fig. 6 Effect of LRRC8A/VRAC disruption on insulin secretion in vitro and in vivo and on glucose tolerance. a Insulin release from single islets stimulated by high glucose, tolbutamide, and potassium. Islets were incubated for 30 min under the indicated conditions and insulin concentrations in the supernatant were measured. Number of islets is indicated in bars (derived from 5 mice per genotype ( $25 \mathrm{mM}$ glc), 1 mouse per genotype (TOLB), 3 mice per genotype $(\mathrm{KCl}), 2$ mice per genotype (TOLB $+\mathrm{glc})$ ). $\mathbf{b}$ Insulin release of single islets under the indicated conditions during the first 8 min of incubation. Number of islets (from three mice per genotype and condition) is indicated in bars. ${ }^{\star \star \star} p<0.001$ (one-way ANOVA, Tukey's test). c Glucose tolerance test. Changes in

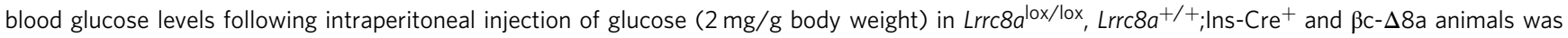
followed over time. $\mathbf{d}$ Insulin tolerance test. Changes in blood glucose levels over time following intraperitoneal injection of insulin (0.75 $\mathrm{U} / \mathrm{kg}$ body weight). c, d Number of mice (male adults, 10-15 weeks old) for each experiment is indicated. ${ }^{*} p<0.05,{ }^{* *} p<0.01$ (two-way ANOVA, Bonferroni multiple comparisons); mean values \pm SEM. e Glucose-stimulated insulin secretion in vivo. Changes in the plasma insulin concentration after intraperitoneal injection of a glucose load ( $2 \mathrm{mg} / \mathrm{g}$ body weight) over time. Number of mice (adult males and females, 10-15 weeks of age) is indicated. Unpaired $t$-test for insulin levels at $2 \mathrm{~min}$ after glucose injection yields $p=0.07$ 
(Fig. 6e) suggested that early insulin secretion of $\beta c-\Delta 8 \mathrm{a}$ mice is impaired, agreeing with our results on $\beta$-cell excitability and insulin secretion in vitro. Although, like in every gene disruption experiment, we cannot totally exclude secondary effects, we conclude that LRRC8/VRAC channels of $\beta$-cells modulate insulin secretion and the regulation of blood glucose.

\section{Discussion}

Serum glucose concentration is subject to complex regulatory mechanisms mainly involving glucose-mobilizing glucagon and glucose-lowering insulin. These hormones are produced and secreted by pancreatic islet $\alpha$ - and $\beta$-cells, respectively. Their secretion is not only controlled by serum glucose, but also by other hormones such as incretins, neurotransmitters, and paracrine/autocrine mechanisms within the islet ${ }^{1,45-47}$. Glucose sensing by $\beta$-cells crucially involves inhibition of $\mathrm{K}_{\mathrm{ATP}}$ channels by intracellular ATP/ADP ratios, which rise owing to increased glucose uptake and metabolism ${ }^{2}$. Our work reveals an important modulatory role of LRRC8/VRAC channels in $\beta$-cell stimulussecretion coupling. These chloride channels depolarize $\beta$-cells in response to glucose-induced $\beta$-cell swelling, thereby enhancing the glucose-induced increase in cytoplasmic $\mathrm{Ca}^{2+}$ and insulin secretion. The presence of neurotransmitter-permeable LRRC8Dcontaining VRACs in $\beta$-cells raises the possibility that they may also be involved in autocrine and paracrine signaling in islets.

Evidence has accumulated over many years that ion channels other than $\mathrm{K}_{\mathrm{ATP}}$ may be involved in glucose-induced $\beta$-cell depolarization and insulin secretion ${ }^{3}$. Prime candidates are $\mathrm{Cl}^{-}$ channels since their opening leads to a depolarizing $\mathrm{Cl}^{-}$efflux in the presence of the high intracellular $\mathrm{Cl}^{-}$concentration of $\beta$ cells ${ }^{11,13}$. Recently the cystic fibrosis transmembrane conductance regulator CFTR has been implicated in modulating the glucose response and insulin secretion of $\beta$-cells ${ }^{9}$. Together with the destruction of pancreatic tissue in certain forms of the disease, reduced CFTR-stimulated insulin secretion might contribute to diabetes in some patients with cystic fibrosis. CFTR needs intracellular ATP for gating, but it is unclear whether glucoseinduced increase in $[\mathrm{ATP}]_{\mathrm{i}}$ can account for the apparently glucose-induced opening of this cAMP-gated channel. VRAC has emerged as another attractive candidate for a $\mathrm{Cl}^{-}$channel that modulates insulin secretion ${ }^{7}$. However, the anion selectivity previously reported for $I_{\mathrm{Cl}, \mathrm{vol}}$ in $\beta$-cells ${ }^{19,20}$ does not fit to canonical VRAC/LRRC8 channels ${ }^{17,25,39,48}$ and the mystery surrounding its molecular identity ${ }^{21,49}$ for a long time has precluded conclusive studies both in vitro and in vivo.

We have now demonstrated conclusively that $I_{\mathrm{Cl} \text {,vol }}$ of $\beta$-cells is mediated by LRRC8 channels, i.e., canonical VRACs displaying a $\mathrm{I}^{-}>\mathrm{Cl}^{-}$selectivity. Opening LRRC8 channels by hypotonicity can depolarize $\beta$-cells up to the threshold for action potential firing. Although the extent of hypotonicity used in our experiments is clearly non-physiological, these experiments provide proof of principle that swelling-activation of LRRC8 channels can depolarize $\beta$-cells to voltages that depend on the magnitude of glucose-induced $\mathrm{K}_{\mathrm{ATP}}$ inhibition. The situation is more complex with exposure to high glucose. It both inhibits $\mathrm{K}_{\mathrm{ATP}}$ channels by the slow increase in ATP/ADP ratios, and slowly activates LRRC8 channels, probably by cell swelling that may be due to osmotic effects of several glucose metabolites including lactate ${ }^{7,40,42}$. Glucose activation of VRAC and inhibition of $\mathrm{K}_{\mathrm{ATP}}$ have a similar time course that is largely determined by the accumulation of glucose metabolites. As shown by the delayed, but otherwise normal response of $\beta c-\Delta 8$ a cells to high glucose, VRAC is clearly not required for glucose-induced excitation of $\beta$-cells, but modulates their glucose sensitivity. Accordingly a marked effect of VRAC on insulin secretion was only observed at $8 \mathrm{~min}$ of glucose addition to isolated islets. When sampled over $30 \mathrm{~min}$, differences in insulin secretion failed to reach significance levels. Importantly, however, $\beta$-cell-specific disruption of VRAC led to significantly impaired glucose tolerance and glucose-induced insulin secretion appeared to be decreased in vivo.

While this manuscript was under review, Sah and coworkers asserted ${ }^{50}$ that the LRRC8A subunit (renamed "SWELL1") is a "glucose sensor" required for glucose-induced excitation and insulin secretion of $\beta$-cells. Both studies coincide in that VRAC plays a role in glucose sensitivity of $\beta$-cells in vitro and in vivo and agree in several other aspects. However, in stark contrast to our study, Kang et al. reported that glucose-induced $\mathrm{Ca}^{2+}$ transients and insulin secretion were abolished in $\operatorname{Lrc} 8 a^{-1-} \beta$-cells, rather than only being delayed or decreased as found by us. The suggested absolute requirement for $\mathrm{VRAC}^{50}$ is surprising in view of the rather mild phenotypes of $\beta$-cell-specific $\operatorname{Lrc} 8 a^{-} /-$mice and unchanged resting glucose levels in either study, and also because the major, canonical $\mathrm{K}_{\mathrm{ATP}}$ pathway for glucose sensing remains intact upon $L r r c 8 a$ disruption. Moreover, consistent with VRAC being closed at rest, both studies reported that the resting potential of $L r r c 8 a^{-1-} \beta$-cells is unchanged. This virtually eliminates the possibility that $\beta$-cell hyperpolarization counteracts the depolarizing effect of $\mathrm{K}_{\mathrm{ATP}}$ closure in $\mathrm{Lrcc} 8 \mathrm{a}^{-1-}$ mice. A possible explanation for the discrepancy between both studies might be found in methodological differences. Whereas we used $\beta$-cells from $\beta c-\Delta 8$ a mice, Kang et al. ${ }^{50}$ more acutely disrupted $\operatorname{Lrc} 8 \mathrm{a} a$ with adenoviral transduction of Cre-recombinase into $\operatorname{Lrc} 8 a^{\text {lox/ }}$ lox cells, or alternatively reduced $\operatorname{Lrc} 8 a$ expression by transduction of shRNA. Whereas in our study the lack of VRAC might have been compensated by altered expression of other channels (although the $\mathrm{K}_{\mathrm{ATP}}$ pathway appeared unchanged), the acute viral overexpression of either Cre-recombinase or shRNA by Kang et al. ${ }^{50}$ might have caused secondary changes that further decreased the glucose sensitivity of $\operatorname{Lrc} 8 a^{-1-} \beta$-cells. Another decisive factor may be the rather short exposure of $\beta$-cells to glucose used by Kang et al. ${ }^{50}$, who thus may have missed the delayed glucose response of $\mathrm{KO}$ cells found here.

Several aspects of $\beta$-cell LRRC8/VRAC channels need to be considered. First, VRAC-dependent cell volume regulation is not essential for the survival, development, and overall function of $\beta$ cells, probably because cells dispose of several redundant mechanisms for regulating their volume ${ }^{16}$. Importantly, $\beta$-cellspecific $\operatorname{Lrc} 8$ a disruption did not affect pancreas and islet morphology, $\beta$-cell mass, insulin content, Kir6.2 expression, the response to tolbutamide, and did not cause inflammation. Hence our results are unlikely to be influenced by developmental or compensatory changes. Second, although VRAC needs basal levels of ATP for channel activity ${ }^{17,51}$, it is not activated by intracellular ATP. Glucose activation of VRAC is most likely caused by osmotic cell swelling due to glucose metabolites ${ }^{7,40,42}$, a notion that is bolstered by our study. Multiple mechanisms have been proposed to explain volume-activation of $\operatorname{VRAC}^{17,49}$, including a direct activation by low intracellular ionic strength $^{27,52,53}$. Third, VRAC might only have a transient role in glucose-stimulated insulin secretion because its opening will lead to an efflux of chloride and organic osmolytes such as taurine 25,54 , resulting in RVD and a subsequent downregulation of VRAC activity. Although we could not detect RVD in glucoseswollen $\beta$-cells over a period of $12 \mathrm{~min}$ (Fig. 3a), which might be owed to continued generation of intracellular glucose-derived osmolytes, a transient role of VRAC in the initial response to glucose is indeed suggested by our experiments (Fig. $5 \mathrm{c}, \mathrm{g}, \mathrm{h}$, Fig. 6a, b). Fourth, VRAC may play a role in autocrine and paracrine signaling in pancreatic islets. LRRC8 channels not only conduct chloride, but also organic compounds including osmolytes, drugs, and neurotransmitters ${ }^{25,29,30,55}$. Transport of these 
compounds is determined by the LRRC8 subunit composi$\operatorname{tion}^{29,30}$. Intriguingly, LRRC8D, a subunit important for the transport of all organic compounds tested so far ${ }^{29,30}$, shows much stronger expression in islets than in whole pancreas (Fig. 1a) and is abundantly expressed in $\beta$-cells (Fig. 1b). LRRC8D-containing VRACs conduct, for instance, taurine ${ }^{29}$, an agonist of glycine and GABA receptors ${ }^{56}$, GABA $^{30}$, glycine ${ }^{57}$ and glutamate ${ }^{30}$. $\beta$-cells express GABA-synthesizing glutamate decarboxylases ${ }^{58}$ and display sizeable cytoplasmic concentrations of $\mathrm{GABA}^{58-61}$. Therefore, in addition to vesicular discharge ${ }^{12,46,62}$, neurotransmitters and regulators might be released from $\beta$-cells through LRRC8/ VRAC channels. Both $\alpha$ - and $\beta$-cells express glycine and GABA receptors ${ }^{12,61-63}$ that may influence glucose homeostasis by stimulating $\beta$-cells in an autocrine fashion or by exerting a paracrine effect on glucagon secretion by $\alpha$-cells. In addition to the direct depolarization by VRAC-mediated $\mathrm{Cl}^{-}$efflux, VRAC might additionally influence systemic glucose homeostasis by autocrine/ paracrine effects within islets.

\section{Methods}

Animals. Animals were housed under standard conditions in the MDC animal facility according to institutional guidelines. All animal experiments were approved by German authorities (LAGeSo) in a letter to the MDC. Mice heterozygous for the targeted $\operatorname{Lrc} 8 a$ allele $\left(\operatorname{Lrc} 8 a^{\operatorname{tm} 2 a(E U C O M M) H m g u}\right)$ were generated by injecting targeted ES cells (obtained from EUCOMM (European Conditional Mouse Mutagenesis Program) consortium) into blastocysts (MDC Transgenic Facility). Lrr $8 a^{\text {tm } 2 a(E U C O M M) H m g u}$ animals were crossed to Cre- or Flp-recombinase expressing deleter mice ${ }^{64,65}$ to generate two different $\operatorname{Lrc} r 8 a$ mouse models (Supplementary Fig. 1). For $\beta$-cell-specific $\operatorname{Lrc} 8 a$ deletion, $\operatorname{Lrc} 8 a^{\text {lox }} / \mathrm{lox}$ mice were crossed to Ins2-Cre ( $\mathrm{Tg}$ (Ins2-cre)23Herr) mice, which express the Cre-recombinase under the control of the rat insulin2 promotor $^{31}$. Ins2-Cre animals were also crossed to Rosa26-Cre reporter line (B6.Cg-Gt(ROSA)26Sor tm9(CAG-tdTomato)Hze /J) 66 to verify cell-type specificity of Cre expression (Supplementary Fig. 6a). Although the Ins2-Cre ( $\mathrm{Tg}$ (Ins2-cre)23Herr) mouse expresses the recombinase also in sparse cells scattered over the brain ${ }^{67,68}$, which we confirmed by crossing this strain with reporter mice (Supplementary Fig. 6b), this is not a concern since Kang et al. ${ }^{50}$ used the recommended Ins1Cre $e^{E R T 2}$ strain to delete $\operatorname{Lrc} 8 a$ and obtained results in vivo similar to ours. Knock-in mice expressing an LRRC8D-tdTomato fusion protein from the endogenous $L r r c 8 d$ promoter were generated by CRISPRCas9 mediated recombination in fertilized mouse oocytes that were implanted into foster mothers by the MDC Transgenic Facility. Sequence encoding the tdTomato fluorescent protein $^{69}$ was added to the carboxy-terminus of LRRC8D. Control experiments indicated that the tag did not change the electrophysiological properties or expression of LRRC8D in transfected cells. The generation and characterization of these mice will be described in detail elsewhere. The fluorescence of the fusion protein was insufficient for detection in tissue sections, requiring immunohistochemistry with anti-RFP-antibodies visualization of the fusion protein. All mice were in a C57/BL6 genetic background.

Antibodies and western blots. Rabbit polyclonal antibodies against individual LRRC8 subunits had been generated in our laboratory and their specificity had been confirmed in western blots using KO cell lines as controls as described ${ }^{25,29,30}$. The following commercial antibodies were used: guinea pig anti-insulin (Dako, A0564; 1:500), mouse anti-glucagon (Abcam, ab10988; $1: 1000)$, mouse anti- $\beta$-actin (Sigma, A2228; 1:2000), rabbit anti-RFP (Rockland, 600401379; 1:1000), rabbit anti-Kir6.2 (Abgent, AG1143; 1:200), goat anti-NLRP3 (Lifespan Biosciences, LSB1766; 1:200), rabbit anti-active caspase 3 (Promega; G748A1; 1:400). Secondary antibodies were from Molecular Probes (coupled to Alexa-488 or Alexa-555 or Alexa 633), or from Jackson ImmunoResearch (coupled to horseradish peroxidase). Quantification of western blots used ImageJ. LRRC8A levels were normalized to actin controls on the same blot. Uncropped western blots are shown in Supplementary Fig. 7.

Histology and immunohistochemistry. For histology, deeply anesthetized mice were perfused with PBS, followed by PBS containing $4 \%$ paraformaldehyde (PFA). Dissected pancreas were postfixed overnight in $4 \%$ PFA, dehydrated in a graded isopropanol series, and then incubated in isopropanol/paraffin $(1: 1)$ mixture overnight at $65^{\circ} \mathrm{C}$. The tissue was embedded in paraffin and cut in $8 \mu \mathrm{m}$ sections which were stained with hematoxylin and eosin $\mathrm{Y}$ (H\&E) according to standard procedure. To prepare frozen tissue sections, tissue from perfused animals was postfixed for $45 \mathrm{~min}$ in $4 \% \mathrm{PFA}$, incubated in $30 \%$ sucrose overnight at $4{ }^{\circ} \mathrm{C}$, and embedded in Tissue-Tek O.C.T. (Sakura). Frozen sections of $8 \mu \mathrm{m}$ were cut using a cryostat (Microm HM 560, Thermo Fisher Scientific). For X-Gal staining, sections were first stained with eosin $\mathrm{Y}$, washed in $0.1 \mathrm{M}$ phosphate buffer $(\mathrm{pH} \mathrm{7.4,} \mathrm{con-}$ taining $2 \mathrm{mM} \mathrm{MgCl}_{2}, 5 \mathrm{mM}$ EGTA, $0.02 \% \mathrm{NP}-40,0.01 \%$ Na-deoxycholate), and then incubated for $15 \mathrm{~h}$ at $37^{\circ} \mathrm{C}$ in $0.1 \mathrm{M}$ phosphate buffer ( $\mathrm{pH}$ 7.4) containing $\mathrm{X}$ Gal $1 \mathrm{mg} / \mathrm{ml}, 2 \mathrm{mM} \mathrm{MgCl}$, $5 \mathrm{mM}$ EGTA, 0.2\% NP-40, 0.1\% Na-deoxycholate, 5 $\mathrm{mM} \mathrm{K}_{3} \mathrm{Fe}(\mathrm{CN})_{6}, 5 \mathrm{mM} \mathrm{K}_{4} \mathrm{Fe}(\mathrm{CN})_{6}$. Images of $\mathrm{H} \& \mathrm{E}$ or X-Gal stainings were taken with an AxioCam MRc 5 camera on an Axiophot microscope using the ZEN software (all from Zeiss). Immunohistochemistry was performed on frozen tissue sections permeabilized with $0.2 \%$ Triton X-100 in PBS, blocked for $30 \mathrm{~min}$ in blocking buffer (PBS containing $0.1 \%$ Triton X-100, 3\% BSA) and incubated overnight at $4{ }^{\circ} \mathrm{C}$ with primary antibodies in blocking buffer. Sections were incubated with secondary antibodies and counterstained with DAPI (Invitrogen) for 45 min at room temperature. Confocal images were taken with a Zeiss LSM 510 microscope using the ZEN software.

Islet purification and primary cell culture. Eight- to 18-week-old mice of either sex were killed by cervical dislocation. The bile duct was clamped before inflating the pancreas with HBSS. The inflated pancreas was dissected, cut into smaller pieces and digested for $11 \mathrm{~min}$ at $37^{\circ} \mathrm{C}$ using $15 \mathrm{ml} \mathrm{HBSS}$ containing $20 \mathrm{mg}$ collagenase from Clostridium histolyticum (Sigma, C9407-5G) with vigorous shaking every $2 \mathrm{~min}$. Digestion was stopped with ice-cold HBSS and islets were further purified from exocrine tissue using a Histopaque gradient and centrifugation for $10 \mathrm{~min}$ at $800 \times g$ (Heraeus Multifuge 31 ). Histopaque 1119 (Sigma, 11191) was diluted with HBSS to obtain solutions with different densities $(1.119,1.1,1.108$, $1.106 \mathrm{~g} / \mathrm{ml}$ ). Islets were transferred to RPMI 1640 and manually isolated under microscopic control. Purified islets were incubated in RPMI 1640 (containing 10\% FCS, $1 \%$ pen/strep) at $37^{\circ} \mathrm{C}$ and $5 \% \mathrm{CO}_{2}$ overnight before performing further experiments. Primary $\beta$-cell cultures were prepared by dispersing the purified islets using an enzyme-free cell dissociation solution (Millipore, S-004-B) and cultured in RPMI 1640 (10\% FCS, 1\% pen/strep). Single isolated $\beta$-cells were used for patchclamp and calcium measurement.

Insulin secretion in vitro. Single islets of similar size were transferred to a 96-well plate and were subsequently incubated at $37^{\circ} \mathrm{C}$ on a shaking platform (300 r.p.m.) for $30 \mathrm{~min}$ each in solutions containing different stimuli. Afterwards islets were lysed and released insulin was normalized to the total islet insulin content. Standard secretion buffer contained (in $\mathrm{mM}$ ) $98 \mathrm{NaCl}, 0.9 \mathrm{CaCl}_{2}, 2.7 \mathrm{KCl}, 1.5 \mathrm{KH}_{2} \mathrm{PO}_{4}$, $0.5 \mathrm{MgCl}_{2}, 8 \mathrm{Na}_{2} \mathrm{HPO}_{4}, 20$ HEPES, 0.2\% BSA, pH 7.4 with $\mathrm{NaOH}$. Different concentrations of glucose $(3.3,10$ or $25 \mathrm{mM})$ or $300 \mu \mathrm{M}$ tolbutamide were added and the osmolarity of the solutions was balanced by adding mannitol ( $290 \mathrm{mOsm})$. Islets that showed morphological changes indicative of lysis or cell death at the end of the secretion period were excluded from the analysis. Islets were lysed afterwards to normalize secreted insulin amounts to the total insulin content. Insulin levels in the supernatant or from total pancreatic lysates were measured using an ultrasensitive insulin ELISA (Alpco, 80-INSMSU-E01) according to manufacturer's instructions. The genotype of islets was revealed only after the end of the experiment.

Cytoplasmic $\mathrm{Ca}^{2}+$ measurements. Single $\beta$-cells or intact islets were seeded on poly-L-lysine (PLL) coated glass bottom live-cell dishes $24 \mathrm{~h}$ before. Cells or islets were washed with bath solution containing (in $\mathrm{mM}$ ) $120 \mathrm{NaCl}, 5 \mathrm{KCl}, 1 \mathrm{MgCl}_{2}, 2.5$ $\mathrm{CaCl}, 20 \mathrm{HEPES}$, and 3 glucose (pH 7.4). Bath solution containing 6, 8, 10, or 15 $\mathrm{mM}$ glucose were used for stimulation and osmolarity of the solutions was compensated by mannitol $(290 \mathrm{mOsm})$. Cells or islets were loaded with Fura-2 AM (Invitrogen) $(5 \mu \mathrm{M})$ at $37^{\circ} \mathrm{C}$ for $30 \mathrm{~min}$. After washing with bath solution, live-cell dishes were mounted on an Axiovert 200 microscope (Zeiss) and alternatively excited at $\lambda=340$ or $380 \mathrm{~nm}$ (Polychrome V TILL Photonics) while emission signals were recorded at $\lambda=510 \mathrm{~nm}$. The ratio of $340 / 380$ fluorescence was calculated and values were normalized to $F_{0}$. Solutions containing 6,8 , or $15 \mathrm{mM}$ glucose were added after $60 \mathrm{~s}$ and the fluorescence was measured every $15 \mathrm{~s}$. To measure $\mathrm{Ca}^{2+}$ oscillations in intact islets, these were already stimulated with 10 $\mathrm{mM}$ glucose solution $30 \mathrm{~min}$ before the experiment. $\mathrm{Ca}^{2+}$ oscillations were measured in the continued presence of $10 \mathrm{mM}$ glucose. Fura-2 fluorescence ratios were measured every $3 \mathrm{~s}$ for $20 \mathrm{~min}$.

Electrophysiology. Single $\beta$-cells, being bigger than other pancreatic cells, were identified by their size and granular appearance and showed a membrane capacitance of $>5 \mathrm{pF}$. They were cultured on PLL-coated coverslips $24-48 \mathrm{~h}$ before recording. Whole-cell patch-clamp recordings were performed using isotonic solution containing (in $\mathrm{mM}$ ) $130 \mathrm{NaCl}, 5 \mathrm{KCl}, 1 \mathrm{MgCl}_{2}, 2.5 \mathrm{CaCl}_{2}, 20 \mathrm{HEPES}, 20$ mannitol, pH 7.4 with $\mathrm{NaOH}(310 \mathrm{mOsm})$ or hypotonic solution containing (in mM) $105 \mathrm{NaCl}, 5 \mathrm{CsCl}, 1 \mathrm{MgCl}_{2}, 2.5 \mathrm{CaCl}_{2}, 20$ HEPES, pH 7.4 (240 mOsm). To determine ion selectivity, $105 \mathrm{mM} \mathrm{NaCl}$ was substituted by $105 \mathrm{mM} \mathrm{NaI}$. Glucoseactivated $I_{\mathrm{Cl} \text {,vol }}$ was measured in isotonic solution with $20 \mathrm{mM}$ glucose substituting mannitol ( $\mathrm{pH} 7.4,310 \mathrm{mOsm}$ ). The patch pipette solution contained (in $\mathrm{mM}$ ) 100 $\mathrm{CsCl}, 20$ tetraethylammonium-Cl, 10 HEPES, $4 \mathrm{MgATP}, 5$ EGTA, $1.93 \mathrm{CaCl}_{2}$ (calculated free $\mathrm{Ca}^{2+}: 50-100 \mathrm{nM}$ ), 25 mannitol (pH 7.2 with $\mathrm{CsOH}, 290 \mathrm{mOsm}$ ). The holding potential was set to $-30 \mathrm{mV}$. A ramp protocol from -80 to $80 \mathrm{mV}$ (Fig. 2b) was run every $15 \mathrm{~s}$ to record the time course of $I_{\mathrm{Cl} \text {,vol }}$ activation. Following complete activation of $I_{\mathrm{Cl}, \mathrm{vol}}$, a step voltage protocol was applied ( -80 to $100 \mathrm{mV}$ in $20 \mathrm{mV}$ steps every $5 \mathrm{~s}$ (Fig. 2c)). Relative anion permeability was calculated as described $^{25}$. 
Membrane potentials were measured by gramicidin-perforated patch-clamp recordings in the current clamp mode $(I=0)$. The pipette solution contained (in mM) $138 \mathrm{KCl}, 10 \mathrm{NaCl}, 1 \mathrm{MgCl}_{2}, 10 \mathrm{HEPES}, \mathrm{pH} 7.2$ with $\mathrm{KOH}(290 \mathrm{mOsm})$ and freshly added $25 \mu \mathrm{g} / \mathrm{ml}$ gramicidin (Sigma, G5002). Electrical access with a resistance of $<50 \mathrm{M} \Omega$ was obtained after 5-15 min. Cells were superfused with isotonic solutions containing (in $\mathrm{mM}$ ) $120 \mathrm{NaCl}, 5 \mathrm{KCl}, 1 \mathrm{MgCl}_{2}, 2.5 \mathrm{CaCl}_{2}, 20$ HEPES, pH 7.4 and different glucose $(1,5$, or 15$)$ concentrations, with osmolarity adjusted to $290 \mathrm{mOsm}$ with mannitol. Hypotonic solutions contained $90 \mathrm{NaCl}, 5$ $\mathrm{KCl}, 1 \mathrm{MgCl}_{2}, 2.5 \mathrm{CaCl}_{2}, 20$ HEPES, pH 7.4 and different glucose (1 or 5) concentrations $(220 \mathrm{mOsm})$. All recordings were performed at room temperature. We used an EPC-10 patch-clamp amplifier controlled with the PatchMaster software (HEKA). Data were analyzed using the software pClamp 10.6 (Molecular Devices). Patch pipettes were pulled to a resistance of $2-5 \mathrm{M} \Omega$.

$\boldsymbol{\beta}$-cell mass and pancreatic mass. $\beta$-cell mass was calculated from immunohistochemical stainings as the ratio of insulin-positive area to total pancreatic tissue area, each of which was measured from three different tissue sections per animal (two animals per genotype) using ImageJ and multiplied by the weight of the organ. The relative pancreatic mass was measured as the ratio of the organ weight to body weight.

Cell volume measurements of $\boldsymbol{\beta}$ cells. Cell volume measurements employed the calcein method ${ }^{70}$. Cells were loaded with $4 \mu \mathrm{M}$ calcein AM (Affymetrix eBiosciences) at $37^{\circ} \mathrm{C}$ for $30 \mathrm{~min}$. Live-cell dishes mounted on an Axiovert 200 microscope (Zeiss) were extensively washed with isosmotic solution. Cells were recorded for $2 \mathrm{~min}$ in isosmotic solution (in $\mathrm{mM}$ : $90 \mathrm{NaCl} ; 1 \mathrm{MgCl}_{2} ; 2 \mathrm{CaCl}_{2} ; 10$ glucose; 10 HEPES; 100 mannitol pH 7.4; 310 mOsm before switching to hypotonic solution $(210 \mathrm{mOsm})$, in which mannitol was omitted). For glucose stimulation experiments, cells were superfused and recorded for a minimum of $5 \mathrm{~min}$ in $3 \mathrm{mM}$ glucose-containing isosmotic solution (same as used for cytoplasmic $\mathrm{Ca}^{2+}$ measurements; $290 \mathrm{mOsm}$ ) and then exposed to $25 \mathrm{mM}$ glucose-containing isosmotic solution. Isotonicity of 3 and $25 \mathrm{mM}$ glucose solutions was achieved with mannitol. For recordings, fluorescence was excited at $\lambda=496 \mathrm{~nm}$ while emission signals were recorded at $\lambda=510 \mathrm{~nm}$ (Polychrome V, TILL Photonics) and images acquired at $30 \mathrm{~s}$ intervals. Fluorescence of selected ROIs was measured. Data are presented as $F$ $-F_{0}$ values, where $F_{0}$ is the fluorescence in isosmotic solution at time 0 , and $F$ is the fluorescence at time $t$.

In vivo experiments. Adult male mice were fasted for $4 \mathrm{~h}$ prior to intraperitoneal injection of glucose ( $2 \mathrm{mg} / \mathrm{g}$ body weight). Blood was withdrawn from the tail and glucose levels were measured with a blood glucose meter (Contour XT, Bayer) at time points $0,15,30,60$, and $120 \mathrm{~min}$ post injection. Following a $48 \mathrm{~h}$ resting period, the same animals used for the GTT were again injected intraperitoneally with insulin $(0.75 \mathrm{U} / \mathrm{kg}$ body weight) and blood glucose levels were measured as described before. GSIS was performed at the Mouse Metabolic Evaluation Facility (MEF) in Lausanne (Switzerland) according to their experimental design and institutional guidelines. Animals were intraperitoneally injected with glucose (2 $\mathrm{mg} / \mathrm{g}$ body weight) and blood was withdrawn from the tail vein $60 \mathrm{~min}$ before, as well as 2 and $15 \mathrm{~min}$ after glucose injection. Plasma insulin levels were evaluated using an insulin-ELISA. In all cases, the genotype of the animals was only revealed after the completion of the experiment.

Data availability. The data that support the findings of this study are available from the corresponding author upon reasonable request.

Received: 4 August 2017 Accepted: 23 April 2018

Published online: 17 May 2018

\section{References}

1. Rorsman, P. \& Braun, M. Regulation of insulin secretion in human pancreatic islets. Annu. Rev. Physiol. 75, 155-179 (2013).

2. Ashcroft, F. M. \& Rorsman, P. $\mathrm{K}_{\mathrm{ATP}}$ channels and islet hormone secretion: new insights and controversies. Nat. Rev. Endocrinol. 9, 660-669 (2013).

3. Henquin, J. C., Nenquin, M., Ravier, M. A. \& Szollosi, A. Shortcomings of current models of glucose-induced insulin secretion. Diabetes Obes. Metab. 11, 168-179 (2009).

4. Seghers, V., Nakazaki, M., DeMayo, F., Aguilar-Bryan, L. \& Bryan, J. Sur1 knockout mice. A model for $\mathrm{K}_{\mathrm{ATP}}$ channel-independent regulation of insulin secretion. J. Biol. Chem. 275, 9270-9277 (2000).

5. Ravier, M. A., Nenquin, M., Miki, T., Seino, S. \& Henquin, J. C. Glucose controls cytosolic $\mathrm{Ca}^{2+}$ and insulin secretion in mouse islets lacking adenosine triphosphate-sensitive $\mathrm{K}^{+}$channels owing to a knockout of the pore-forming subunit Kir6.2. Endocrinology 150, 33-45 (2009).

6. Nenquin, M., Szollosi, A., Aguilar-Bryan, L., Bryan, J. \& Henquin, J. C. Both triggering and amplifying pathways contribute to fuel-induced insulin secretion in the absence of sulfonylurea receptor-1 in pancreatic $\beta$-cells. J. Biol. Chem. 279, 32316-32324 (2004).
7. Best, L., Brown, P. D., Sener, A. \& Malaisse, W. J. Electrical activity in pancreatic islet cells: the VRAC hypothesis. Islets 2, 59-64 (2010).

8. Koivula, F. N., McClenaghan, N. H., Harper, A. G. \& Kelly, C. Islet-intrinsic effects of CFTR mutation. Diabetologia 59, 1350-1355 (2016).

9. Guo, J. H. et al. Glucose-induced electrical activities and insulin secretion in pancreatic islet $\beta$-cells are modulated by CFTR. Nat. Commun. 5, 4420 (2014).

10. Sehlin, J. Interrelationship between chloride fluxes in pancreatic islets and insulin release. Am. J. Physiol. 235, E501-E508 (1978).

11. Eberhardson, M., Patterson, S. \& Grapengiesser, E. Microfluorometric analysis of $\mathrm{Cl}^{-}$permeability and its relation to oscillatory $\mathrm{Ca}^{2+}$ signalling in glucosestimulated pancreatic $\beta$-cells. Cell. Signal. 12, 781-786 (2000).

12. Braun, M. et al. Gamma-aminobutyric acid (GABA) is an autocrine excitatory transmitter in human pancreatic $\beta$-cells. Diabetes 59, 1694-1701 (2010).

13. Majid, A., Speake, T., Best, L. \& Brown, P. D. Expression of the $\mathrm{Na}^{+} \mathrm{K}^{+}-2 \mathrm{CI}^{-}$ cotransporter in $\alpha$ and $\beta$ cells isolated from the rat pancreas. Pflüg. Arch. 442, 570-576 (2001).

14. Lindström, P., Norlund, L., Sandström, P. E. \& Sehlin, J. Evidence for cotransport of sodium, potassium and chloride in mouse pancreatic islets. J. Physiol. 400, 223-236 (1988).

15. Miley, H. E., Sheader, E. A., Brown, P. D. \& Best, L. Glucose-induced swelling in rat pancreatic $\beta$-cells. J. Physiol. 504, 191-198 (1997).

16. Jentsch, T. J. VRACs and other ion channels and transporters in the regulation of cell volume and beyond. Nat. Rev. Mol. Cell Biol. 17, 293-307 (2016).

17. Nilius, B. et al. Properties of volume-regulated anion channels in mammalian cells. Prog. Biophys. Mol. Biol. 68, 69-119 (1997).

18. Best, L., Miley, H. E. \& Yates, A. P. Activation of an anion conductance and $\beta$-cell depolarization during hypotonically induced insulin release. Exp. Physiol. 81, 927-933 (1996).

19. Kinard, T. A. \& Satin, L. S. An ATP-sensitive $\mathrm{Cl}^{-}$channel current that is activated by cell swelling, cAMP, and glyburide in insulin-secreting cells. Diabetes 44, 1461-1466 (1995).

20. Best, L., Sheader, E. A. \& Brown, P. D. A volume-activated anion conductance in insulin-secreting cells. Pflüg. Arch. 431, 363-370 (1996).

21. Pedersen, S. F., Klausen, T. K. \& Nilius, B. The identification of VRAC (volume regulated anion channel): an amazing odyssey. Acta Physiol. 213, 868-881 (2015).

22. Kinard, T. A. et al. Chloride channels regulate HIT cell volume but cannot fully account for swelling-induced insulin secretion. Diabetes 50, 992-1003 (2001).

23. Best, L., Yates, A. P., Decher, N., Steinmeyer, K. \& Nilius, B. Inhibition of glucose-induced electrical activity in rat pancreatic $\beta$-cells by DCPIB, a selective inhibitor of volume-sensitive anion currents. Eur. J. Pharmacol. 489 , 13-19 (2004)

24. Best, L., Brown, P. D., Sheader, E. A. \& Yates, A. P. Selective inhibition of glucose-stimulated $\beta$-cell activity by an anion channel inhibitor. J. Membr. Biol. 177, 169-175 (2000).

25. Voss, F. K. et al. Identification of LRRC8 heteromers as an essential component of the volume-regulated anion channel VRAC. Science 344, 634-638 (2014).

26. Qiu, Z. et al. SWELL1, a plasma membrane protein, is an essential component of volume-regulated anion channel. Cell 157, 447-458 (2014).

27. Syeda, R. et al. LRRC8 proteins form volume-regulated anion channels that sense ionic strength. Cell 164, 499-511 (2016).

28. Ullrich, F., Reincke, S. M., Voss, F. K., Stauber, T. \& Jentsch, T. J. Inactivation and anion selectivity of volume-regulated anion channels (VRACs) depend on C-terminal residues of the first extracellular loop. J. Biol. Chem. 291 , 17040-17048 (2016).

29. Planells-Cases, R. et al. Subunit composition of VRAC channels determines substrate specificity and cellular resistance to Pt-based anti-cancer drugs. ЕМВО J. 34, 2993-3008 (2015).

30. Lutter, D., Ullrich, F., Lueck, J. C., Kempa, S. \& Jentsch, T. J. Selective transport of neurotransmitters and modulators by distinct volume-regulated LRRC8 anion channels. J. Cell Sci. 130, 1122-1133 (2017)

31. Herrera, P. L. Adult insulin- and glucagon-producing cells differentiate from two independent cell lineages. Development 127, 2317-2322 (2000).

32. Segerstolpe, A. et al. Single-cell transcriptome profiling of human pancreatic islets in health and type 2 diabetes. Cell Metab. 24, 593-607 (2016).

33. Rorsman, P., Eliasson, L., Kanno, T., Zhang, Q. \& Gopel, S. Electrophysiology of pancreatic $\beta$-cells in intact mouse islets of Langerhans. Prog. Biophys. Mol. Biol. 107, 224-235 (2011).

34. Decher, N. et al. DCPIB is a novel selective blocker of $\mathrm{I}_{\mathrm{Cl}, \text { swell }}$ and prevents swelling-induced shortening of guinea-pig atrial action potential duration. $\mathrm{Br}$. J. Pharmacol. 134, 1467-1479 (2001).

35. Friard, J. et al. Comparative effects of chloride channel inhibitors on LRRC8/ VRAC-mediated chloride conductance. Front. Pharmacol. 8, 328 (2017).

36. Bowens, N. H., Dohare, P., Kuo, Y. H. \& Mongin, A. A. DCPIB, the proposed selective blocker of volume-regulated anion channels, inhibits several glutamate transport pathways in glial cells. Mol. Pharmacol. 83, 22-32 (2013). 
37. Minieri, L. et al. The inhibitor of volume-regulated anion channels DCPIB activates TREK potassium channels in cultured astrocytes. Br. J. Pharmacol. 168, 1240-1254 (2013).

38. Best, L., Speake, T. \& Brown, P. Functional characterisation of the volumesensitive anion channel in rat pancreatic $\beta$-cells. Exp. Physiol. 86, 145-150 (2001).

39. Pedersen, S. F., Okada, Y. \& Nilius, B. Biophysics and physiology of the volume-regulated anion channel (VRAC)/volume-sensitive outwardly rectifying anion channel (VSOR). Pflüg. Arch. 468, 371-383 (2016).

40. McGlasson, L., Best, L. \& Brown, P. D. The glucokinase activator GKA50 causes an increase in cell volume and activation of volume-regulated anion channels in rat pancreatic $\beta$-cells. Mol. Cell. Endocrinol. 342, 48-53 (2011).

41. Best, L., Miley, H. E., Brown, P. D. \& Cook, L. J. Methylglyoxal causes swelling and activation of a volume-sensitive anion conductance in rat pancreatic ß-cells. J. Membr. Biol. 167, 65-71 (1999).

42. Best, L. \& Brown, P. D. Studies of the mechanism of activation of the volumeregulated anion channel in rat pancreatic $\beta$-cells. J. Membr. Biol. 230, 83-91 (2009).

43. Bertram, R., Sherman, A. \& Satin, L. S. Electrical bursting, calcium oscillations, and synchronization of pancreatic islets. Adv. Exp. Med. Biol. 654, 261-279 (2010).

44. Brouwers, B. et al. Impaired islet function in commonly used transgenic mouse lines due to human growth hormone minigene expression. Cell Metab. 20, 979-990 (2014).

45. Caicedo, A. Paracrine and autocrine interactions in the human islet: more than meets the eye. Semin. Cell Dev. Biol. 24, 11-21 (2013).

46. Braun, M., Ramracheya, R. \& Rorsman, P. Autocrine regulation of insulin secretion. Diabetes Obes. Metab. 14, 143-151 (2012).

47. Campbell, J. E. \& Drucker, D. J. Pharmacology, physiology, and mechanisms of incretin hormone action. Cell Metab. 17, 819-837 (2013).

48. Okada, Y. Cell volume-sensitive chloride channels: phenotypic properties and molecular identity. Contrib. Nephrol. 152, 9-24 (2006).

49. Okada, Y. Volume expansion-sensing outward-rectifier $\mathrm{Cl}^{-}$channel: fresh start to the molecular identity and volume sensor. Am. J. Physiol. 273, C755-C789 (1997).

50. Kang, C. et al. SWELL1 is a glucose sensor regulating $\beta$-cell excitability and systemic glycaemia. Nat. Commun. 9, 367 (2018).

51. Jackson, P. S., Morrison, R. \& Strange, K. The volume-sensitive organic osmolyte-anion channel VSOAC is regulated by nonhydrolytic ATP binding. Am. J. Physiol. 267, C1203-C1209 (1994).

52. Emma, F., McManus, M. \& Strange, K. Intracellular electrolytes regulate the volume set point of the organic osmolyte/anion channel VSOAC. Am. J. Physiol. 272, C1766-C1775 (1997).

53. Nilius, B., Prenen, J., Voets, T., Eggermont, J. \& Droogmans, G. Activation of volume-regulated chloride currents by reduction of intracellular ionic strength in bovine endothelial cells. J. Physiol. 506, 353-361 (1998).

54. Grant, A. C., Thomson, J., Zammit, V. A. \& Shennan, D. B. Volume-sensitive amino acid efflux from a pancreatic $\beta$-cell line. Mol. Cell. Endocrinol. 162, 203-210 (2000).

55. Lee, C. C., Freinkman, E., Sabatini, D. M. \& Ploegh, H. L. The protein synthesis inhibitor blasticidin S enters mammalian cells via leucine-rich repeat-containing protein 8D. J. Biol. Chem. 289, 17124-17131 (2014).

56. Le-Corronc, H., Rigo, J. M., Branchereau, P. \& Legendre, P. GABA A $_{\text {receptor }}$ and glycine receptor activation by paracrine/autocrine release of endogenous agonists: more than a simple communication pathway. Mol. Neurobiol. 44, 28-52 (2011).

57. Gaitán-Peñas, H. et al. Investigation of LRRC8-mediated volume-regulated anion currents in Xenopus oocytes. Biophys. J. 111, 1429-1443 (2016).

58. Kim, J. et al. Differential expression of GAD65 and GAD67 in human, rat, and mouse pancreatic islets. Diabetes 42, 1799-1808 (1993)

59. Okada, Y., Taniguchi, H. \& Schimada, C. High concentration of GABA and high glutamate decarboxylase activity in rat pancreatic islets and human insulinoma. Science 194, 620-622 (1976).

60. Taniguchi, H. et al. High concentration of $\gamma$-aminobutyric acid in pancreatic $\beta$ cells. Diabetes 28, 629-633 (1979).

61. Gammelsaeter, R. et al. Glycine, GABA and their transporters in pancreatic islets of Langerhans: evidence for a paracrine transmitter interplay. J. Cell Sci. 117, 3749-3758 (2004).

62. Yan-Do, R. et al. A glycine-insulin autocrine feedback loop enhances insulin secretion from human $\beta$-cells and is impaired in type 2 diabetes. Diabetes $\mathbf{6 5}$, 2311-2321 (2016).

63. Li, C. et al. Regulation of glucagon secretion in normal and diabetic human islets by $\gamma$-hydroxybutyrate and glycine. J. Biol. Chem. 288, 3938-3951 (2013).
64. Schwenk, F., Baron, U. \& Rajewsky, K. A cre-transgenic mouse strain for the ubiquitous deletion of loxP-flanked gene segments including deletion in germ cells. Nucleic Acids Res. 23, 5080-5081 (1995).

65. Farley, F. W., Soriano, P., Steffen, L. S. \& Dymecki, S. M. Widespread recombinase expression using FLPeR (flipper) mice. Genesis 28, 106-110 (2000).

66. Madisen, L. et al. A robust and high-throughput Cre reporting and characterization system for the whole mouse brain. Nat. Neurosci. 13, 133-140 (2010).

67. Magnuson, M. A. \& Osipovich, A. B. Pancreas-specific Cre driver lines and considerations for their prudent use. Cell Metab. 18, 9-20 (2013).

68. Wicksteed, B. et al. Conditional gene targeting in mouse pancreatic $\beta$-cells: analysis of ectopic Cre transgene expression in the brain. Diabetes 59, 3090-3098 (2010)

69. Shaner, N. C. et al. Improved monomeric red, orange and yellow fluorescent proteins derived from Discosoma sp. red fluorescent protein. Nat. Biotechnol. 22, 1567-1572 (2004)

70. Capó-Aponte, J. E., Iserovich, P. \& Reinach, P. S. Characterization of regulatory volume behavior by fluorescence quenching in human corneal epithelial cells. J. Membr. Biol. 207, 11-22 (2005)

\section{Acknowledgements}

We thank Johanna Jedamzick and Carolin Backhaus for technical assistance, Dr. Tobias Stauber for help in generating $L r r c 8 a^{\text {lox/lox }}$ mice from targeted EUCOMM ES cells, Dr. Fréderic Preitner (Mouse Metabolic Facility, Université de Lausanne) for in vivo insulin secretion experiments, and Dr. Mathew Poy and Dr. Sudhir Tattikota for advice in establishing pancreatic islet purification and insulin secretion measurements. This work was supported by European Research Council (ERC) Advanced Grants (FP7/2007-2013) 294435 "Cytovolion" and (Horizon 2020) 740537 "Volsignal," the Deutsche Forschungsgemeinschaft (Exc257 "Neurocure"), and the Prix Louis-Jeantet de Médecine to T.J.J.

\section{Author contributions}

T.S. designed, performed, and evaluated the majority of the experiments, including western blots, electrophysiology and $\mathrm{Ca}^{2+}$ imaging, islet insulin secretion, and in vivo experiments. R.P.-C. designed, generated, and analyzed knock-in mice expressing epitope-tagged LRRC8D, and performed and evaluated cell volume measurements and immunohistochemistry. T.J.J. initiated the study, designed, and evaluated experiments, and wrote the paper. T.S. and R.P.-C. contributed to the writing, prepared figures, and commented on the paper.

\section{Additional information}

Supplementary Information accompanies this paper at https://doi.org/10.1038/s41467018-04353-y.

Competing interests: The authors declare no competing interests.

Reprints and permission information is available online at http://npg.nature.com/ reprintsandpermissions/

Publisher's note: Springer Nature remains neutral with regard to jurisdictional claims in published maps and institutional affiliations.

Open Access This article is licensed under a Creative Commons Attribution 4.0 International License, which permits use, sharing, adaptation, distribution and reproduction in any medium or format, as long as you give appropriate credit to the original author(s) and the source, provide a link to the Creative Commons license, and indicate if changes were made. The images or other third party material in this article are included in the article's Creative Commons license, unless indicated otherwise in a credit line to the material. If material is not included in the article's Creative Commons license and your intended use is not permitted by statutory regulation or exceeds the permitted use, you will need to obtain permission directly from the copyright holder. To view a copy of this license, visit http://creativecommons.org/ licenses/by/4.0/

(c) The Author(s) 2018 